\title{
Insights on geochemical cycling of $U$, Re and Mo from seasonal sampling in Boston Harbor, Massachusetts, U.S.A.
}

$$
\begin{gathered}
\text { Jennifer L. Morford }^{\mathrm{a}^{*}} \\
\text { William R. Martin }^{\mathrm{a}} \\
\text { Linda H. Kalnejais }^{\mathrm{a}} \\
\text { Roger François }^{\mathrm{a} \dagger} \\
\text { Michael Bothner }^{\mathrm{b}} \\
\text { Ida-Maja Karle }^{\mathrm{c}}
\end{gathered}
$$

${ }^{\mathrm{a}}$ Woods Hole Oceanographic Institution

Marine Chemistry and Geochemistry Department, Woods Hole, MA USA 02543

$$
\begin{gathered}
{ }^{\mathrm{b}} \text { United States Geological Survey, Woods Hole Science Center, } \\
\text { Woods Hole, MA 02543-1598 }
\end{gathered}
$$

${ }^{\mathrm{c}}$ Dept. of Analytical and Marine Chemistry, Göteborg University, SE-412 96 Gothenburg, SWEDEN

\footnotetext{
${ }^{\dagger}$ Currently at Department of Earth and Ocean Sciences, University of British Columbia, Vancouver, British Columbia, Canada V6T 1 Z4

*Corresponding author, currently at Franklin \& Marshall College, Department of Chemistry, P.O. Box 3003, Lancaster, PA 17604-3003, phone (717) 358-4590; fax (717) 291-4343; email jennifer.morford@fandm.edu
}

Submitted to Geochimica et Cosmochimica Acta March 17, 2006 Accepted on October 23, 2006

Please cite as: Morford, J.L. et al., Insights on geochemical cycling of U, Re and Mo from seasonal. . ., Geochim. Cosmochim. Acta (2006), doi: 10.1016/j.gca.2006.10.016 


\begin{abstract}
This study examined the removal of U, Mo, and Re from seawater by sedimentary processes at a shallow-water site with near-saturation bottom water $\mathrm{O}_{2}$ levels (240-380 $\mu \mathrm{mol} \mathrm{O}_{2} / \mathrm{L}$ ), very high organic matter oxidation rates (annually averaged rate is $870 \mu \mathrm{mol} \mathrm{C} / \mathrm{cm}^{2} / \mathrm{y}$ ), and shallow oxygen penetration depths (4 $\mathrm{mm}$ or less throughout the year). Under these conditions, U, Mo, and Re were removed rapidly to asymptotic pore water concentrations of $2.2-3.3 \mathrm{nmol} / \mathrm{kg}(\mathrm{U}), 7-13 \mathrm{nmol} / \mathrm{kg}(\mathrm{Mo})$, and $11-14 \mathrm{pmol} / \mathrm{kg}$ $(\mathrm{Re})$. The order in which the three metals were removed, determined by fitting a diffusion-reaction model to measured profiles, was $\mathrm{Re}<\mathrm{U}<$ Mo. Model fits also suggest that the Mo profiles clearly showed the presence of a near-interface layer in which Mo was added to pore waters by remineralization of a solid phase. The importance of this solid phase source of pore water Mo increased from January to October as the organic matter oxidation rate increased, bottom water $\mathrm{O}_{2}$ decreased, and the $\mathrm{O}_{2}$ penetration depth decreased. Experiments with in situ benthic flux chambers generally showed fluxes of U and Mo into the sediments. However, when the overlying water $\mathrm{O}_{2}$ concentration in the chambers was allowed to drop to very low levels, Mn and Fe were released to the overlying water along with the simultaneous release of Mo and U. These experiments suggest that remineralization of Mn and/or Fe oxides may be a source of Mo and perhaps $\mathrm{U}$ to pore waters, and may complicate the accumulation of $\mathrm{U}$ and Mo in bioturbated sediments with high organic matter oxidation rates and shallow $\mathrm{O}_{2}$ penetration depths.
\end{abstract}


Benthic chamber experiments including the nonreactive solute tracer, $\mathrm{Br}^{-}$, indicated that sediment irrigation was very important to solute exchange at the study site. The enhancement of sediment-seawater exchange due to irrigation was determined for the nonreactive tracer $\left(\mathrm{Br}^{-}\right), \mathrm{TCO}_{2}, \mathrm{NH}_{4}{ }^{+}, \mathrm{U}$ and $\mathrm{Mo}$. The comparisons between these solutes showed that reactions within and around the burrows were very important for modulating the Mo flux, but less important for U. The effect of these reactions on Mo exchange was highly variable, enhancing Mo (and, to a lesser extent, U) uptake at times of relatively modest irrigation, but inhibiting exchange when irrigation rates were faster. These results reinforce the observation that Mo can be released to and removed from pore waters via sedimentary reactions.

The removal rate of $U$ and Mo from seawater by sedimentary reactions was found to agree with the rate of accumulation of authigenic $U$ and Mo in the solid phase. The fluxes of $U$ and Mo determined by in situ benthic flux chamber measurements were the largest that have been measured to date. These results confirm that removal of redoxsensitive metals from continental margin sediments underlying oxic bottom water is important, and suggest that continental margin sediments play a key role in the marine budgets of these metals. 


\section{INTRODUCTION}

Redox-sensitive metal concentrations in sediment cores have been used to determine past changes in reducing conditions (e.g. Calvert and Pedersen, 1993; François et al., 1993, 1997; Dean et al., 1994, 1997; Rosenthal et al., 1995; Crusius et al., 1996, 2000; Anderson et al., 1998; Adelson et al., 2001; Nameroff et al., 2004). The reducing conditions in the aqueous and solid phases of sediments can be identified by the presence or absence of redox-sensitive trace metals (RSMs) in the solid phase. Because individual RSMs can behave differently under reducing conditions, analyzing a select suite of RSMs can provide additional information regarding conditions at the time of solid phase accumulation. The species studied here, uranium (U), rhenium (Re) and molybdenum (Mo), are all soluble under oxic conditions, and precipitate (or adsorb) under anoxic conditions (bottom water oxygen concentration equals zero, $\mathrm{O}_{2, \mathrm{bw}}=0$ ). However, their behavior is variable under intermediate reducing conditions where $\mathrm{O}_{2, \mathrm{bw}} \neq 0$, but where oxygen penetrates a centimeter or less $\left(\mathrm{O}_{2, \text { pen }} \leq 1 \mathrm{~cm}\right)$ below the sediment-water interface before it is consumed. Changes in solid phase RSM concentrations deposited over time can suggest changes in reducing conditions over that time period. Reducing conditions in sediments are influenced by both the carbon flux to sediments and the bottom water oxygen concentration, but the relative importance of these agents in controlling reducing conditions in sediments is not fully understood. A better understanding of the mechanisms and conditions controlling RSM incorporation in the solid phase and the potential for release from the solid phase will aid in the interpretation of RSM accumulation. 
Other complications on the use of RSMs involve the present understanding of their respective global mass balances. Morford and Emerson (1999) suggest that sinks approximately balance sources for $\mathrm{U}$ and Mo, whereas sinks far exceed apparent sources for Re. These mass balances are based on the area of reducing sediments at water depths $>1000 \mathrm{~m}$ where $\mathrm{O}_{2 \text {,pen }} \leq 1 \mathrm{~cm}$, which make up approximately $4 \%$ of the ocean sediment area (Morford and Emerson, 1999). The importance of shallower sediments, where water depth is less than $1000 \mathrm{~m}$, as sinks or sources of RSMs has not been adequately quantified. In an attempt to include shallower sediments, Archer et al. (2002) used a diagenetic model with data on $\mathrm{O}_{2}$ concentration and organic carbon rain rate vs. water depth to estimate that $\sim 20 \%$ of the seafloor has $\mathrm{O}_{2, \text { pen }} \leq 1 \mathrm{~cm}$. Although this determination does not differentiate between sandy and muddy sediments, the result is five times greater than the area determined for water depths greater than $1000 \mathrm{~m}$ and suggests that the reducing nature of shallow sediments may make them a large sink for RSMs.

Another complicating factor is the potential for changes to metal accumulation after authigenic enrichment (i.e., diagenesis) that might obscure the connection between authigenic metal accumulation and reducing conditions at the time of accumulation. Diagenesis may be of particular importance in coastal areas where changes in the depth of oxygen penetration due to seasonal variations in overlying productivity and bottom water oxygen concentration or changes in the extent of bioturbation may compromise the accumulation of RSMs. Co-cycling of RSMs with manganese (Mn) oxides and/or iron (Fe) oxyhydroxides (which will be referred to more generally as oxides throughout this paper) might also result in diagenetic alteration. Manganese and/or Fe oxide layers will 
be found in surface sediments even where $\mathrm{O}_{2 \text {,pen }}$ is shallow, providing reactive surfaces for trace metal adsorption. A shoaling in the $\mathrm{O}_{2 \text {,pen }}$ could result in reductive dissolution of $\mathrm{Mn}$ and/or Fe oxides, thereby releasing adsorbed species to pore waters and overlying waters. Therefore, the importance of coastal sediments as a sink (or source) of RSMs and the effect of diagenesis on the burial and preservation of RSMs is uncertain.

Understanding the geochemical cycling of RSMs in coastal environments, which undergo seasonal changes in bottom water oxygen concentration, organic carbon flux, bioturbation and irrigation, should clarify the diagenetic cycling of RSMs and will ultimately improve the utility of RSMs as paleoredox tracers. Therefore, both the similar and contrasting behaviors of $U, \operatorname{Re}$ and Mo cycling in a coastal setting (Hingham Bay, Massachusetts, U.S.A.) are described here. The impact of seasonal variability in the rates of benthic processes is explored by contrasting results from winter (January), early summer (June, July) and early fall (September, October). Results from traditionally sliced and centrifuged sediment cores, polyacrylamide gel probes, and benthic chambers are presented, and further interpreted through the application of a one-dimensional steady-state pore water model.

\subsection{Study Site}

The study site is in southeastern Boston Harbor in Hingham Bay, east of Peddocks Island, at $42^{\circ} 17^{\prime} 52.9^{\prime \prime} \mathrm{N}, 70^{\circ} 55^{\prime} 40.0^{\prime \prime} \mathrm{W}$ (Fig. 1). The mean water depth is $5 \mathrm{~m}$. Sediments are $6 \%$ sand, $62 \%$ silt, and $32 \%$ clay, and surface sediments are $3.2 \%$ organic C (Kalnejais, 2005). This site is one of several long-term monitoring locations in Boston Harbor (Bothner et al., 1998). We sampled pore waters and sedimentary solids for U, Mo, 
and Re on three occasions in 2001, and measured fluxes of the metals directly with in situ benthic flux chambers in June 2001 and in January and October 2002. In describing sedimentary redox conditions and organic matter cycling, we include pore water and flux measurements made from January 2001 through June 2004.

Like all of Boston Harbor, this site has a complex depositional history. In 1978, the sedimentation rate was determined to be $1.8 \mathrm{~cm} \mathrm{y}^{-1}$ (Bothner et al., 1998). The sedimentation rate has decreased dramatically in recent years, largely because of reduced anthropogenic inputs to the harbor in response to federal law. A reduction in solids and nutrient discharge to the harbor was achieved by: (1) stopping sewage sludge discharge in December, 1991; (2) initiating repair of combined sewage-runoff overflows; (3) phasing in secondary sewage treatment from 1997-2001; and (4) moving the outfall for sewage effluent $15.2 \mathrm{~km}$ offshore in September 2000. The average sedimentation rate from 19782000 was determined by comparing the depths of the ${ }^{137}$ Cs peak in cores taken in 1978 and 2000. The estimated rate was $0.6 \mathrm{~cm} \mathrm{y}^{-1}$ (M. Bothner, unpublished data).

The major input of organic matter to the seafloor is from local primary production (Taylor, 2005; Libby et al., 2004a,b). Primary production at a nearby harbor site north of Peddocks Island ranged from 2600-4900 $\mu \mathrm{mol} \mathrm{C} \mathrm{cm}^{-2} \mathrm{y}^{-1}$ from 2001-2003, with the highest value in 2002 and the lowest in 2003. In general, there is a small peak in primary production in the spring (March), and the annual maximum is in September (Libby et al., 2002, 2003, 2004a,b).

Water column properties vary seasonally. Salinity ranges from $\sim 30-32 \mathrm{psu}$, with the annual minimum in June. The temperature range is from $\sim 0-16^{\circ} \mathrm{C}$, with the annual maximum being in July (Libby et al., 2002; 2003; 2004a,b). The oxygen concentration 
remains close to saturation throughout the water column throughout the year, with maximum values of $\sim 380 \mu \mathrm{M}$ in February, and minimum values of $\sim 240 \mu \mathrm{M}$ in early fall.

\section{METHODS AND ANALYTICAL PROCEDURES}

\subsection{Sampling Methods}

Visually undisturbed cores were collected either using a pole and coring tube operated from a small boat (January 2001) or by SCUBA divers (all other times). Cores were either sampled immediately in a van on the dock (January 2001) or kept cool by surrounding them with ice packs during transport to Woods Hole, where they were sampled in a refrigerated room $\left(\sim 4^{\circ} \mathrm{C}\right)$ under $\mathrm{N}_{2}$ within 4 hours of collection. An additional core was used for porosity and sediment resistivity determinations. This core was allowed to come to room temperature before sampling, $\sim 24$ hours after collection. Following sectioning, sediment samples were centrifuged at 10,000 rpm for 10-15 minutes. Pore waters were taken up into plastic syringes for nutrients and $\mathrm{TCO}_{2}$, and into all-plastic, acid-cleaned and $18 \mathrm{M} \Omega$ MilliQ (MQ) water rinsed syringes for trace metals. Pore waters were filtered under $\mathrm{N}_{2}$ through $0.45 \mu \mathrm{m}$ Acrodisc HT Tuffryn membrane filters. $\mathrm{TCO}_{2}$ samples were filtered into $1-\mathrm{cm}^{3}$ syringes and stored in ice water to be run within 24 hours. Nutrient samples were filtered into polyethylene vials and analyzed within 24 hours. Trace metal samples were filtered into 4-mL HDPE bottles. Concentrated nitric acid (40 $\mu \mathrm{L}$, Fisher Optima Grade) had been added to the bottles before sample addition. Prior to fieldwork, syringes and filters for trace metals were cleaned with $2 \mathrm{M} \mathrm{HCl}$, rinsed with $\mathrm{MQ}$ water, and dried in a laminar flow hood. Trace metal sample storage bottles were cleaned by filling with $2 \mathrm{M} \mathrm{HCl}$, heating for 4 days at 
$60^{\circ} \mathrm{C}$, rinsing with MQ water, and drying in a laminar flow hood. Syringes, filters, and plastic vials for nutrients were cleaned with MQ water and dried in a laminar flow hood.

In addition to the cores that were sampled immediately, two cores were kept in the cold room for a $\sim 24$ hour incubation, during which the overlying waters were continuously exchanged with bottom water from a large reservoir. This exchange created an internal circulation for the overlying water. One of these cores was sampled at the end of the 24-hour period exactly as the rapidly-sampled cores. This core served as a control core, to ensure that the incubations did not dramatically alter the pore water profiles compared to the pore water profiles in the cores that were immediately sampled. The second incubated core was used to sample pore waters by equilibrating a polyacrylamide gel housed in an acrylonitrile butadiene styrene probe with the core. The probe was purchased from DGT Research, Ltd., modified and prepared as described in Morford et al., 2003. Probes were covered with a $0.1 \mu \mathrm{m}$ polycarbonate membrane and deoxygenated prior to use by placing the probes in an electrolyte solution $\left(\mathrm{NaCl} / \mathrm{MgSO}_{4}\right)$ at in situ salinity, and bubbling the solution with $\mathrm{N}_{2}$ for 72 hours. Probes were removed from the $\mathrm{O}_{2}$-free solution immediately ( $\sim 15$ seconds) before insertion into the sediments. Rapid insertion into the sediments was essential, as exposure to $\mathrm{O}_{2}$ can lead to the formation of oxides during the equilibration period. Following a 24-hour equilibration period (Morford et al., 2003), probes were removed from the sediments, the membrane was discarded, and discrete gel sections were stored in pre-weighed microcentrifuge vials. Dilute (5\%, Fisher Optima grade) $\mathrm{HNO}_{3}$ was added to each vial for metal extraction. 
Benthic fluxes were measured directly using in situ benthic flux chambers.

Chamber design was similar in most respects to that of Sayles and Dickinson (1991). The most significant difference is that chambers used for this work can be operated in both a "standard" mode, in which the concentrations of all solutes are allowed to vary, or in an " $\mathrm{O}_{2}$-controlled" mode. In the $\mathrm{O}_{2}$-controlled mode, bottom water is pumped continuously through a $2 \mathrm{~m}$ coil of silicone tubing placed within the chamber, allowing gas exchange across the tubing walls. After several hours, the $\mathrm{O}_{2}$ concentration in the chamber reaches a steady state in which the rate of addition by diffusion across the tubing equals the rate of loss by sedimentary $\mathrm{O}_{2}$ consumption. The oxygen flux is calculated using laboratorydetermined permeability values for the tubing. Laboratory experiments indicated that gas exchange across the tubing had only a minor effect on in situ $\mathrm{TCO}_{2}$ flux determinations. Chamber samples were collected in aluminosilicate glass ampoules that had been prefilled with MQ water. A spring-loaded syringe behind each ampoule drew $50 \mathrm{~mL}$ of chamber water through the ampoule; studies of $\mathrm{Cl}^{-}$concentration in the resulting chamber samples showed that dilution of the final, $20 \mathrm{~mL}$ samples by distilled water was negligible ( $<1 \%$; W. Martin, unpublished data). A maximum of 8 samples, spaced over a 4-day period, was taken during each deployment. At the start of each deployment, dissolved $\mathrm{NaBr}$ was added to the overlying water to increase the dissolved $\mathrm{Br}$ concentration to about $5 \mathrm{x}$ its in situ value. The decreasing $\mathrm{Br}^{-}$concentrations in the chamber were used to quantify nondiffusive solute transport (Martin and Banta, 1992; Sayles and Martin, 1995; Martin and Sayles, 2004). Chambers, sample lines, and ampoules were cleaned by soaking for several days in $0.1 \mathrm{M} \mathrm{HCl}$, followed by rinsing and soaking in MQ water. 


\subsection{Analytical Procedures}

Precision was determined by analyzing duplicate samples. Pore water nutrients were determined, with a precision of $1 \%$, by autoanalyzer using methods adapted from Glibert and Loder (1977). $\mathrm{TCO}_{2}$ was analyzed by an automated procedure in which samples are acidified with phosphoric acid, the $\mathrm{CO}_{2}$ is stripped with $\mathrm{N}_{2}$ gas, and the $\mathrm{CO}_{2}$ evolved is quantified by infrared absorption using a Licor analyzer (O'Sullivan and Millero, 1998). Precision was $\pm 10 \mu \mathrm{mol} \mathrm{kg}^{-1}$ for flux chamber samples and was $\pm 20 \mu \mathrm{mol}$ $\mathrm{kg}^{-1}$ for pore water samples. Oxygen analyses were by small-volume Winkler titration $( \pm 2 \%)$. Dissolved sulfide was measured using the Cline (1969) method with a detection limit of $2 \mu \mathrm{M}$. Br- was determined by ion chromatography with a precision of $\pm 2 \%$.

Trace metals were measured using the WHOI Finnigan Element high resolution inductively coupled plasma mass spectrometer (ICP-MS). U and Mo benthic chamber samples were measured using isotope dilution $\left({ }^{236} \mathrm{U}\right.$ and ${ }^{95} \mathrm{Mo}$, respectively) to achieve high precision results. Duplicate analyses of benthic chamber samples show a precision of $\pm 2 \%$. We used a modification of the Rodushkin and Ruth (1997) method, which uses internal standards, for $\mathrm{Mn}, \mathrm{Fe}, \mathrm{U}, \mathrm{Re}$, and $\mathrm{Mo}$ in 20 -fold diluted pore water and gel probe samples. Replicate measurements $(n=23)$ of a standard seawater solution (CASS-4, Nearshore seawater for trace metals, National Research Council of Canada) indicate that the instrumental method precision for a 20 -fold dilute seawater solution is $<10 \%$ for Mo and $\mathrm{U}$ and $<11 \%$ for $\mathrm{Re}$ and Mn. The average concentration for Mo is within its certified $95 \%$ confidence range, whereas the average Mn concentration is approximately $8 \%$ above the CASS-4 certified concentration. Although U does not have a certified value for 
CASS-4, our average measurement was $13 \%$ below its suggested value. The lack of $\mathrm{U}$ and $\mathrm{Mn}$ accuracy does not affect calculated fluxes since flux calculations depend on concentration differences. Re is not certified and the certified Fe concentration was below the detection limit for this method $(0.013 \mu \mathrm{M})$.

The solid sample remaining after centrifugation was freeze-dried and ground for solid phase analyses. Solid phase metals were analyzed by the United States Geological Survey (USGS) using a total digestion/ICP-MS procedure (Briggs and Meier, 1999). Sediment standards (BCSS-1, MESS-1, PACS-2 from the National Research Council of Canada and MAG-1 from the United States Geological Survey) were used to assess accuracy. For standards with certified concentrations, measurements of $\mathrm{Fe}, \mathrm{Mn}, \mathrm{U}$ and Mo were either within certified ranges (Mn: all standards; Fe: MESS-1, MAG-1; U: MAG-1; Mo: PACS-2) or slightly high (Fe was 4 to $6 \%$ high in PACS-2 and BCSS-1). Excess ${ }^{234} \mathrm{Th}$ and ${ }^{210} \mathrm{~Pb}$ were analyzed by direct counting on Canberra LeGe detectors (Sayles et al., 2001). Porosity and resistivity were determined by the methods of Manheim et al. (1974) and Andrews and Bennett (1981), respectively, using procedures that we have described previously (Martin and Sayles, 2004).

\section{MODELS OF U, Mo AND Re DIAGENESIS}

\subsection{Model of Pore Water U, Mo, and Re}

The pore water profiles of $\mathrm{U}, \mathrm{Mo}$, and Re are interpreted using a one-dimensional, steady state model. This modeling effort is a means to (1) combine profiles at each time point to generate a "composite" profile, (2) use a curve-fitting procedure to estimate the profile slopes at the sediment-water interface and at the top of the "removal" layer (i.e., at 
the apparent inflection point in the profile), and (3) provide a means of comparing the behaviors of the three RSM. In applying a steady state model to the temporally variable Hingham Bay sediments, we assume that the time scale of seasonal change is long relative to RSM reaction rates. It is important to note that the model does not explicitly include the effects of nondiffusive solute transport (irrigation) on RSM profiles, since these effects are uncertain. The influence of irrigation is discussed separately.

The model includes solute transport by diffusion and burial advection, and includes two sedimentary layers in which distinct reactions occur. In the layer adjacent to the sediment-water interface, the RSMs may be released to pore waters from the solid phase in a zero-order reaction. In the deeper layer, RSMs are removed by a reaction that is first-order in the quantity $\left(\mathrm{C}-\mathrm{C}_{\infty}\right)$, where $\mathrm{C}_{\infty}$ is the asymptotic concentration of the RSM in pore waters. In equation form, $0=\left\{\frac{d}{d x} \phi D_{\text {sed }} \frac{d C}{d x}\right\}-\frac{d}{d x}\{\phi v C\}+\phi R \quad$ (Equation 1)

$\mathrm{C}$ is the concentration of the RSM under consideration. $\mathrm{R}$ is the reaction rate (nmol or pmol $\mathrm{cm}_{\mathrm{pw}}^{-3} \mathrm{y}^{-1}$ ), and it has one functional form for the shallow layer and a different one for the deep layer:

$$
\begin{array}{ll}
x<x_{p} & R=k_{r} \\
x \geq x_{p} & R=-k_{p}\left(C-C_{\infty}\right)
\end{array}
$$

$\mathrm{x}_{\mathrm{p}}$ is the depth in the sediments at which net removal from pore waters begins. $\mathrm{x}_{\mathrm{p}}$ is marked by an inflection point in the pore water profile, and the downward flux of the solute at this depth is the rate of removal of the solute if the system is at steady state on the time scale of the removal process. When $\mathrm{x}<\mathrm{x}_{\mathrm{p}}$, the value for $\mathrm{k}_{\mathrm{r}}$ represents the potential release of RSMs from the solid to the aqueous phase. When $x \geq x_{p}$, the rate of 
loss is equivalent to the product of $\mathrm{k}_{\mathrm{p}}$ and the difference in concentration $\left(\mathrm{C}-\mathrm{C}_{\infty}\right)$.

Differences in the removal process between the RSMs are paramaterized by variation in $\mathrm{C}_{\infty}$ and $\mathrm{k}_{\mathrm{p}}$.

The surface layer, in which there may be net release of a RSM from the solid phase to the pore water, may be: (1) absent if $x_{p}=0$, (2) a layer of no net reaction if $x_{p}>$ 0 but $\mathrm{k}_{\mathrm{r}}=0$, or (3) a layer of net release if $\mathrm{x}_{\mathrm{p}}>0$ and $\mathrm{k}_{\mathrm{r}}>0$.

Porosity $(\phi)$ is allowed to vary exponentially with depth as a function of the form $\phi=a+b e^{-c x} \quad$ (Equation 2)

The parameters $(\mathrm{a}, \mathrm{b}$, and $\mathrm{c})$ are determined by least squares fits to the measured porosity versus depth profiles (Martin and Sayles, 1987; Martin and Banta, 1992). $D_{\text {sed }}$ is the diffusion coefficient for the solute in sediments $\left(\mathrm{cm}_{\text {sed }}^{2} \mathrm{y}^{-1}\right)$. The effect of sediment tortuosity on $\mathrm{D}_{\text {sed }}$ is experimentally determined by resistivity measurements to determine the formation factor $(\mathrm{F})$, which is the ratio of sediment resistivity to that of pore water (McDuff and Ellis, 1979).

$D_{\text {sed }}=\frac{D_{p w}}{\phi F} \quad($ Equation 3$)$

Four determinations of $\phi(\mathrm{x})$ and $\mathrm{F}$ were made at this site, two in early summer and two in early fall (data not shown). The two time periods gave somewhat different relationships between $\mathrm{F}$ and $\phi$, as $v$ in the Winsauer relationship, $F=c \phi^{-v}$, differed between the seasons (Table 1). Differences between the time periods were not large enough to affect model results. In modeling pore water data, we used the early summer relationships to approximate the parameters for the January time point. 
The ionic diffusion coefficient in pore water $\left(\mathrm{D}_{\mathrm{pw}}\right)$ is assumed to be equal to that in seawater. The diffusion coefficients of the species that are important for this work are not well known: $\mathrm{D}_{\mathrm{sw}}$ for Mo was taken from Li and Gregory (1974); that for U was assumed to be equal to that of Mo, and that for Re was based on Crusius et al. (1996). Previous authors (e.g., McManus et al., 2005) have used the Li and Gregory (1974) value for $\mathrm{UO}_{2}{ }^{2+}$ to describe $\mathrm{U}$ diffusion. However, the dominant $\mathrm{U}$ species is most likely the anionic carbonate complex, which can be expected to have a significantly larger diffusion coefficient than $\mathrm{UO}_{2}{ }^{2+}$. Therefore, we chose to use $\mathrm{D}_{\mathrm{sw}}$ for the anionic species, $\mathrm{MoO}_{4}{ }^{2-}$, to describe U. The formulation of Li and Gregory (1974) was used to calculate the temperature dependence of the diffusion coefficients.

The burial advection rate $\left(\mathrm{v}, \mathrm{cm}_{\text {sed }} \mathrm{y}^{-1}\right)$ varies with depth to maintain a constant sediment accumulation rate (Berner, 1980). The specific value of the accumulation rate has only a minor effect on results. As we discussed earlier, the sediment accumulation rate at the study site has decreased dramatically over the last two decades. We used a value of $0.054 \mathrm{~g}_{\text {solid }} \mathrm{cm}^{-2}$ sed $\mathrm{Y}^{-1}$, which corresponds to a sedimentation rate of $0.1 \mathrm{~cm} \mathrm{y}^{-1}$ at a depth of $\sim 20 \mathrm{~cm}$ (using the dry bulk density of Bothner et al., 1998). This value is smaller than the average sedimentation rate of $0.6 \mathrm{~cm} \mathrm{y}^{-1}$ for the period, 1978-2000, reflecting recent decreases in anthropogenic inputs to Boston Harbor.

\subsection{Treatment of Sediment Irrigation}

As noted above, the model used to interpret pore water profiles of U, Mo, and Re does not explicitly include the effects of nondiffusive transport of the solutes. The reason for the omission is that the effects of sediment irrigation on reactive solutes are difficult 
to predict. We treat sediment irrigation separately in order to determine the role played by these transport processes in RSM cycling at the study site.

In general, there are two components of the flux of a solute across the sedimentwater interface in shallow-water sediments: the diffusive flux, which can be calculated from the gradient of the pore water profile at $\mathrm{x}=0$, and a nondiffusive flux that in finegrained sediments is primarily due to the flushing of infaunal burrows by the actions of infauna and physical processes. The "total" flux, due to both transport processes, is measured using benthic flux chambers. The nondiffusive flux component can be evaluated by subtracting the diffusive flux, calculated from pore water profiles, from the total flux. It is useful to model transport processes to understand the interplay between sedimentary reactions, such as reactions in the burrows and burrow walls, and transport through the burrows which together produce the nondiffusive flux.

We have modeled the process using a method that was pioneered by Christiansen et al. (1984) and Emerson et al. (1984) and placed in a theoretical framework by Boudreau (1984). The procedure treats solute transport by irrigation as a quasi-onedimensional process in which the transport by irrigation between overlying water and bulk sediments, at a given depth in the sediment column, is calculated as the product of a transport parameter ( $\alpha$, in units of time $\left.e^{-1}\right)$ and the difference in concentration of a solute between the pore waters at the given depth and bottom water. Then, the integrated flux from sediments to bottom water due to irrigation is calculated by:

$$
F_{i r r}=\int_{0}^{L} \alpha \phi\left(C(x)-C_{b w}\right) d x
$$


$\phi$ is sediment porosity, $\mathrm{C}$ is the concentration of the solute in pore water, $\mathrm{x}$ denotes depth below the sediment-water interface, and $\mathrm{L}$ is the maximum depth in the sediments to which irrigation occurs. We calculate a "transport-only" $\alpha$ by incorporating this transport term in a model of the time-varying distribution of the non-reactive solute, $\mathrm{Br}^{-}$, which we have added to the overlying water of a flux chamber at the start of a chamber deployment (Martin and Banta, 1992; Martin and Sayles, 2004).

In order to examine the transport of other, reactive solutes, we have introduced two modifications into equation 4. First, we assume that the rate-limiting step in the transport of dissolved solutes by irrigation is diffusion across burrow walls. Then, $\alpha$ for solute i can be calculated from the value determined from equation 4 and $\mathrm{Br}^{-}$data by $\alpha_{i}=\alpha_{B r^{-}} \frac{D_{i}}{D_{B r^{-}}} \quad$ (Equation 5)

Second, we allow for the possibility that reactions within burrows, their walls, and the surrounding sediments may either enhance or diminish the irrigation flux relative to that which would be inferred from the $\mathrm{Br}^{-}$data (Boudreau, 1984; Aller, 2001). For this purpose, we introduce a "reaction factor" for solute $\mathrm{i}, f_{\mathrm{i}}$. The resulting, more general expression for nondiffusive transport of solute $\mathrm{i}\left(\mathrm{I}_{\mathrm{i}}\right)$ is:

$$
\int_{0}^{L} I_{i}(x) d x=\int_{0}^{L} \alpha_{B r}(x) \frac{D_{i}}{D_{B r}} f_{i} \phi\left(C_{i}(x)-C_{i, b w}\right) d x \quad \text { (Equation 6) }
$$

In principle, $f_{\mathrm{i}}$ may vary with depth below the sediment-water interface, but our data only allow the calculation of a depth-averaged value. $f_{\mathrm{i}}$ is calculated by comparing the sum of the diffusive flux, calculated from the pore water gradient at the sediment-water interface $\left(\mathrm{F}_{\mathrm{D}}\right)$, and the "transport-only" irrigation flux for solute i (equation 6 with $f_{\mathrm{i}}=1$, with $\mathrm{C}(\mathrm{x})$ from the pore water profile of i) $\left(\mathrm{F}_{\mathrm{I}}\right)$ to the chamber-determined flux $\left(\mathrm{F}_{\mathrm{C}}\right)$ : 
$f_{i}=\frac{F_{C, i}}{F_{D, i}+F_{I, i}} \quad$ (Equation 7)

A value of $f_{\mathrm{i}}>1$ indicates that reactions in and around burrows enhance the nondiffusive transport of solute $\mathrm{i}$, while a value $<1$ indicates that such reactions inhibit transport.

\section{RESULTS AND DISCUSSION}

The accumulation of RSM in marine sediments has been related to the bottom water dissolved $\mathrm{O}_{2}$ concentration, the rate of organic matter oxidation, and sedimentary Fe and S cycling (e.g. Barnes and Cochran, 1993; Crusius et al., 1996; Zheng et al., 2000, 2002a; McManus et al., 2005). Therefore, in order to set the stage for our discussion of RSM diagenesis, it is necessary to first discuss organic matter oxidation and redox horizons at the Hingham Bay site.

\subsection{Organic Matter Oxidation}

Organic matter oxidation was quantified using pore water and benthic flux data. Pore water data from three time points in 2001 and 2002 are shown in Figure 2. The agreement between two or three cores at each time was very good, as is illustrated by the $\mathrm{NH}_{4}{ }^{+}$versus $\mathrm{TCO}_{2}$ plots in January and September 2002 (Fig. 2). The results are typical of a high-flux, shallow water sedimentary system. Near-interface concentrations of $\mathrm{TCO}_{2}$ and $\mathrm{NH}_{4}^{+}$are lower in winter and spring than in the early fall. The seasonal increase was greater in 2002 than in 2001, consistent with the observation that 2002 was a year of higher regional productivity. In addition, there is a zone of apparent net $\mathrm{NH}_{4}{ }^{+}$removal in the upper $\sim 1-2 \mathrm{~cm}$ of the sediments in winter and spring, but not in early fall, which was a time of highest productivity and water temperature and lowest bottom water $\mathrm{O}_{2}$ 
concentration. Plots of $\mathrm{NH}_{4}{ }^{+}$concentration versus $\mathrm{TCO}_{2}$ concentration in pore waters yield a net production ratio of $0.15 \pm 0.03 \mathrm{~mol} \mathrm{~N} / \mathrm{mol} \mathrm{C}$ over the 2001-2004 period (Fig. 2), very near the $\mathrm{N} / \mathrm{C}$ ratio in Redfield organic matter. Therefore, since $\mathrm{NH}_{4}{ }^{+}$is released subsequent to oxic organic matter oxidation by suboxic and anoxic processes the sediments are dominated by these processes, especially Fe oxide and sulfate reduction.

Diffusive fluxes of $\mathrm{TCO}_{2}$ and $\mathrm{NH}_{4}{ }^{+}$across the sediment water interface, calculated from pore water profiles, are compared to direct, in situ flux measurements (Fig. 3) in Figure 4. In order to emphasize seasonal differences, data from 2001 to 2004 are plotted as flux versus Julian day of measurement, and the error bars on the flux chamber measurement reflect year-to-year as well as spatial variability. In general, directly measured fluxes are greater than diffusive fluxes, with the largest differences occurring in the June/July period. Independent measurements of nondiffusive solute transport rates (discussed below) showed that sediment irrigation was greatest in this time period. The exception to this generalization was in January 2001, when a large difference between direct and diffusive fluxes was measured despite an apparent absence of irrigation (see Fig. 4 caption).

We estimated the annual sediment-seawater exchange of $\mathrm{NH}_{4}{ }^{+}, \mathrm{TCO}_{2}$, and $\mathrm{O}_{2}$ by interpolating between flux chamber data points and calculating the area under the resulting curve. In making this calculation, because of uncertainty about the single January direct flux determination, we averaged the January pore water and flux measurements for $\mathrm{TCO}_{2}$ and $\mathrm{NH}_{4}{ }^{+}$. The annual $\mathrm{NH}_{4}{ }^{+}, \mathrm{TCO}_{2}$, and $\mathrm{O}_{2}$ fluxes calculated in this way were 74,876 , and $1047 \mu \mathrm{mol} \mathrm{cm}^{-2} \mathrm{y}^{-1}$, respectively. Thus, the N/C ratio in the total flux is 0.084 , substantially lower than the production ratio in pore waters. This total 
flux includes near-interface removal of $\mathrm{NH}_{4}{ }^{+}$as well as more efficient transport of $\mathrm{TCO}_{2}$ by irrigation, either because of ammonium adsorption to sedimentary solids or denitrification. The $\mathrm{O}_{2} / \mathrm{TCO}_{2}$ flux ratio is 1.2 , which is close to estimates for the oxidation of marine organic matter by $\mathrm{O}_{2}(\sim 1.4$, Anderson and Sarmiento, 1994). This result is consistent with recycling and reoxidation of reduced products of organic matter oxidation (in particular, $\mathrm{Fe}^{2+}$ and $\mathrm{S}^{2-}$ ) so that, although anoxic processes dominate sedimentary organic matter oxidation, $\mathrm{O}_{2}$ remains the ultimate electron acceptor (e.g., Aller, 1994).

\subsection{Sedimentary redox horizons}

The accumulation of RSMs in sediments has been linked to bottom water $\mathrm{O}_{2}$ concentration, $\mathrm{Mn}$ and $\mathrm{Fe}$ reduction and oxidation, and the presence of $\mathrm{H}_{2} \mathrm{~S}$ in pore waters. Distinct seasonal variations are evident. In January, bottom water $\mathrm{O}_{2}$ is high $(\sim 380 \mu \mathrm{M}), \mathrm{O}_{2}$ is completely removed from pore waters within $0.6 \mathrm{~cm}$ (based on pore water $\mathrm{Fe}^{2+}$ concentrations), and the peak in pore water $\mathrm{Mn}^{2+}$ concentration extends from $0.85-1.1 \mathrm{~cm}$ (Figure 5). In late summer/early fall, bottom water $\mathrm{O}_{2}$ falls to $240 \mu \mathrm{M}$, penetration shoals to less than $0.25 \mathrm{~cm}$ (our thinnest sampling interval), and the pore water $\mathrm{Mn}^{2+}$ peak narrows to $0-0.28 \mathrm{~cm}$. The $\mathrm{Fe}^{2+}$ concentration reaches values of up to $600-800 \mu \mathrm{M}$ at its peak, which occurs from $2-5 \mathrm{~cm}$ below the interface. $\mathrm{Fe}^{2+}$ is removed,

presumably by oxidation, above its peak. The very small benthic flux of dissolved Fe (Fig. 3) shows that Fe is effectively trapped within the sediment column, undergoing repeated oxidation/reduction cycles before being buried. $\mathrm{Fe}^{2+}$ appears to be removed from pore waters below its peak by precipitation as FeS. The scenario that most likely explains the pore water $\mathrm{Fe}^{2+}$ and $\mathrm{H}_{2} \mathrm{~S}$ profiles is that the zones of iron oxide and sulfate reduction 
overlap, leading to essentially complete removal of $\mathrm{H}_{2} \mathrm{~S}$ as $\mathrm{FeS}$ until the easily reducible Fe oxides are exhausted. At $6-8 \mathrm{~cm}$ below the sediment-water interface, the precipitation of FeS has completely removed $\mathrm{Fe}^{2+}$ from the pore water, and $\mathrm{H}_{2} \mathrm{~S}$ begins to accumulate, rapidly reaching levels of 400-1000 $\mu \mathrm{M}$ (Fig. 5). In addition to these high levels of $\mathrm{H}_{2} \mathrm{~S}$, at various depths shallower than 6-8 $\mathrm{cm}$ we measured several $\mathrm{H}_{2} \mathrm{~S}$ concentrations up to $15 \mu \mathrm{M}$, which is above our detection limit of $\sim 2 \mu \mathrm{M}$. Therefore, our measurements do not preclude the presence of small quantities of $\mathrm{H}_{2} \mathrm{~S}$ in the pore waters shallower than 6-8 cm.

Measurements of excess ${ }^{234} \mathrm{Th}$ in the sediments indicate that solid phase mixing may contribute to the internal cycle of reduced products of organic matter oxidation (e.g., Mn, Fe, and S). Although we do not have enough measurements to define seasonal trends (data not shown), the data imply that bioturbation mixing intensities are seasonally variable with lower mixing intensities in January and higher mixing intensities in summer and early fall (Table 2). The excess ${ }^{234} \mathrm{Th}$ data show that a sedimentary constituent with a mean lifetime of $\sim 1$ month can be transported $\sim 2.5-5 \mathrm{~cm}$ by bioturbation. Potential transport distances for longer-lived components that are produced in the upper $5-10 \mathrm{~cm}$ of the sediments are correspondingly longer. Because excess ${ }^{234} \mathrm{Th}$ is introduced at the sediment surface, its penetration depth does not necessarily define the full depth of the rapidly mixed layer; the depth may be set by the presence of high $\mathrm{H}_{2} \mathrm{~S}$ concentrations in pore waters below $6-8 \mathrm{~cm}$.

\subsection{RSM : Pore water profiles}


Pore water profiles of Fe, Mn, U, Re, and Mo from cores taken in January, June, and October of 2001 are shown in Figure 6. There are clear general trends in the profiles of dissolved U, Re, and Mo. Uranium and Re consistently decrease from the sedimentwater interface to nonzero asymptotic values. The Mo profiles differ in that they show a near-surface zone of net release into the pore waters above the zone of net removal. Similar to $\mathrm{U}$ and Re, Mo also eventually decreases to a nonzero asymptotic concentration. The nonzero values at depth are observed in profiles obtained by both sectioning/centrifugation and gel probe equilibration. Although we cannot be certain that concentrations do not decrease further below our maximum sampled depth, the observed values are similar to those that have been found in other locations (Shaw et al., 1990; Klinkhammer and Palmer, 1991; Colodner et al., 1993; Zheng et al., 2000, 2002a; McManus et al., 2005; Morford et al., 2005).

Anomalous pore water features described in the caption to Figure 6 may have been caused by sampling artifacts (from exposure of probes to oxygen prior to probe deployment) or in situ processes not included in the model (irrigation). These features have been omitted from our detailed consideration of RSM diagenesis (Table 1). After the removal of these data, the pore water data for each RSM at each time point were combined into a single, "composite" profile by averaging points in the separate profiles collected from overlapping depth intervals (Fig. 7). The averaging process resulted in a profile-based error bar at each depth. Then, a $\chi^{2}$-minimization procedure (the LevenburgMarquardt method, based on Press et al., 1986) was used with the model (equations 1-4) to describe the profiles in terms of the fitting parameters, $\mathrm{x}_{\mathrm{p}}, \mathrm{k}_{\mathrm{r}}, \mathrm{k}_{\mathrm{p}}$, and $\mathrm{C}_{\infty}$. Ideally, if the calculated error bars $(1 \sigma)$ are appropriate and the model explains the trends in the data 
well, $\frac{\chi^{2}}{n} \sim 1$ (Table 1). This condition is met reasonably well, with two notable

exceptions: (1) the lack of deep data in January means that $\mathrm{C}_{\mathrm{eq}}$ is not well constrained at that time; and (2) when there is a Mo maximum just below the sediment-water interface, the model underestimates its magnitude (see October). In order to fit this maximum better, there would have to be a depth-dependent $\mathrm{k}_{\mathrm{r}}$ term. Model fits of the pore water data are shown in Figure 7.

\subsection{RSM: Diagenesis}

The mode of input of RSM to the sediments is important for both the calculation of net fluxes to the solid phase from pore water data and the interpretation of accumulation rates. In the simplest case, there is no net release of RSM to the pore waters from sedimentary solids. In this case, model parameter $\mathrm{k}_{\mathrm{r}}=0$ and the differences between the accumulation rates of the different RSM are limited to differences in the depth $\left(\mathrm{x}_{\mathrm{p}}\right)$ and rate $\left(\mathrm{k}_{\mathrm{p}}, \mathrm{C}_{\infty}\right)$ of loss. Changes over time would be driven largely by changes in $\mathrm{x}_{\mathrm{p}}$, which in turn would relate to changes in organic matter input flux and/or bottom water $\mathrm{O}_{2}$ concentration. Departures from this simple scenario are known or suspected for $\mathrm{U}$ and Mo. Sediment trap data and comparisons between pore water and solid phase data suggest an additional input of particulate non-lithogenic $U$ that forms in the water column and is delivered to sediments; this fraction is labile under oxic conditions, but preserved in sedimentary solids when bottom water $\mathrm{O}_{2}$ concentrations are $<25 \mu \mathrm{M}$ (Anderson, 1982; Zheng et al., 2002b). Several studies have documented a relationship between Mo and Mn oxides (Bertine and Turekian, 1973; Manheim, 1974; Colodner, 1991; Kato et al., 1995; Crusius et al., 1996; Morford and Emerson, 1999; Breckel et al., 2005), and U 
has been associated with Fe oxides (McKee et al., 1987; Barnes and Cochran, 1993; Church et al., 1996; Duff et al., 2002). Associations between RSM and Mn and Fe oxides not only complicate primary inputs to the sediment column, but also raise the possibility of internal cycling of RSMs with Fe and Mn. In sediments like the Hingham Bay site where rapid bioturbation occurs, reduced, solid phase Fe and Mn may be mixed toward the sediment surface, where they may be re-oxidized. When Fe and Mn oxides form and precipitate from solution, they remove other elements through co-precipitation and/or adsorption. Both the oxides and the associated trace elements can be recycled many times before being lost to the water column or buried. We have used our pore water data, model, and in situ benthic chamber experiments to examine potential release of $\mathrm{U}, \mathrm{Re}$, and Mo from solids to pore waters or overlying waters at the Hingham site.

The composite pore water profiles (Fig. 7) and the parameters describing them (Table 3) show distinct differences between RSMs. Re is the simplest: its profile implies no layer of net release to the pore waters $\left(\mathrm{k}_{\mathrm{r}}=0\right)$ and its removal begins at the sedimentwater interface $\left(\mathrm{x}_{\mathrm{p}}=0\right)$ at all three time points. Its rate of removal increases from January to October as the rate of organic matter oxidation in the sediments increases, bottom water $\mathrm{O}_{2}$ concentration decreases, and redox horizons become shallower. $\mathrm{U}$ presents no strong evidence for a zone of net release to the pore waters: $\mathrm{k}_{\mathrm{r}}=0$ in January and October, and the June profile can be fit equally well both with no net release, and with a small release near the sediment-water interface. $U$ removal begins at $x_{p}=0$ in January, but is deeper than that of Re in June and October $(1.0-1.7 \mathrm{~cm})$. Although the net removal of $\mathrm{U}$ begins at a shallower depth in October than in June, removal is slower, so that the asymptotic concentration is approached at $\sim 7 \mathrm{~cm}$ in October. Mo removal is clearly 
deeper than that of Re or $\mathrm{U}$, which is consistent with previous observations (Colodner et al., 1993; Crusius et al., 1996; Morford et al., 2005). The values of $x_{p}$ for Mo increase systematically from January to October, from $2.5-5.1 \mathrm{~cm}$. As $\mathrm{x}_{\mathrm{p}}$ increases, the rate of removal $\left(\mathrm{k}_{\mathrm{p}}\right)$ increases markedly as well, with the result that the depth at which Mo reaches its asymptotic value is similar $(5-6 \mathrm{~cm})$ throughout the year. The model fits to Mo profiles imply that there is significant net release of Mo from the solid phase to pore waters at $\mathrm{x}<\mathrm{x}_{\mathrm{p}}$, with $\mathrm{k}_{\mathrm{r}}$ increasing from January to October.

Two in situ benthic chamber experiments provide some insight into the mechanisms of release of Mo and possibly $U$ from solids to pore waters. Re was not measured in these experiments. The benthic chambers can be operated either with or without an $\mathrm{O}_{2}$-control mechanism. In the configuration used for this study, the lowest value of chamber-water $\mathrm{O}_{2}$ was $110-150 \mu \mathrm{M}$ (Fig. 3B and C) when $\mathrm{O}_{2}$ control was used. In January and October 2002, we also deployed chambers without $\mathrm{O}_{2}$ control. In these chambers, the $\mathrm{O}_{2}$ concentration was allowed to reach $40 \mu \mathrm{M}$ (January) and $0 \mu \mathrm{M}$ (October) (Fig. 3A and C). When chamber $\mathrm{O}_{2}$ concentrations drop to low values, the $\mathrm{O}_{2}$ penetration depth in the sediments decreases. Eventually, dissolved Mn and Fe are released from the sediments into the chamber. In January, there was a clear release of Mo that began when Mn was released at a slow rate and became more pronounced when Mn and $\mathrm{Fe}$ were released at a higher rate ( $60 \mathrm{hrs})$. There was a possible release of $\mathrm{U}$ after $\mathrm{Fe}$ release began. In October, there were smaller releases of Mo and $U$ at the end of the chamber deployment. These experiments provide evidence that Mo and $\mathrm{U}$ are associated with $\mathrm{Mn}$ and/or Fe oxides and that they are released on short time scales when $\mathrm{Mn}$ and $\mathrm{Fe}$ oxides are reduced. The smaller release in October may be related to internal cycling 
between reduced and solid phases. Kalnejais (2005) found that the release of three other trace metals $(\mathrm{Ag}, \mathrm{Cu}$, and $\mathrm{Pb})$ to subsurface pore waters at this site was closely correlated to Fe release in January and June 2002, but that there was no release of these metals in October. It was hypothesized that repeated cycling of Fe and Mn between oxidized and reduced forms gradually removed adsorbed metals so that $\mathrm{Ag}, \mathrm{Cu}$ and $\mathrm{Pb}$ were no longer associated with the oxides by October. A similar process may influence Mo and U cycling.

The decrease in the apparent release of $\mathrm{U}$ and Mo accompanying $\mathrm{Mn}$ and Fe reduction in October 2002 may not correlate with the 2001 pore water data. The appearance of $\mathrm{H}_{2} \mathrm{~S}$ in the pore waters was approximately $1 \mathrm{~cm}$ deeper in 2001 compared to 2002, and the zone of elevated dissolved Fe in 2001was correspondingly thicker and at approximately double the concentration observed in 2002. This behavior is consistent with more extensive sulfate reduction in 2002, as would be expected from the observation of enhanced local productivity during that year (Libby et al., 2002, 2003). Our observation of more rapidly increasing $\mathrm{TCO}_{2}$ and $\mathrm{NH}_{4}{ }^{+}$in pore waters in 2002, relative to 2001 (Figure 2), is also consistent with an increase in the sulfate reduction rate. Thus, the balance between Fe release by biologically mediated reduction and the removal of pore water $\mathrm{Fe}$ by $\mathrm{FeS}$ precipitation was tipped more in favor of release of $\mathrm{Fe}^{2+}$ to pore water in 2001 and precipitation in 2002.

With these interannual differences in mind, the deeper depths of net $U$ removal from pore waters in June and October in 2001 may be explained by a balance between two chemically distinct, but spatially overlapping processes: a gradually increasing rate of release of $\mathrm{U}$ from $\mathrm{Fe}$ oxides as the rate of Fe reduction increased, and a competing 
removal process under anoxic conditions in the sediments. The gradually increasing importance of net Mo release above $\mathrm{x}_{\mathrm{p}}$ is also explained by an increasing release associated with $\mathrm{Mn}$ and perhaps Fe reduction.

The removal of Mo is closely related to the concentration of $\mathrm{H}_{2} \mathrm{~S}$. The conversion of aqueous molybdate to thiomolybdate is hypothesized to result in scavenging of Mo from sulfidic water (Helz et al., 1996; Erickson and Helz, 2000; Vorlicek and Helz, 2002; Vorlicek et al., 2004). Zheng et al. (2000) proposed that $\sim 0.1 \mu \mathrm{M}$ sulfide is the minimum concentration required to begin Mo-Fe-S precipitation, while $\sim 100 \mu \mathrm{M}$ sulfide is required for Mo precipitation without Fe. Therefore Mo reached its minimum concentration in Hingham Bay pore waters at the same depth at all times of year due to a nearly constant depth of $\mathrm{H}_{2} \mathrm{~S}$ appearance in pore waters.

These results show that the order of net removal depths of the three RSM under the same conditions at a single site was $\operatorname{Re}<\mathrm{U}<$ Mo. While there was no evidence that Re was supplied to the pore waters by diagenesis of solid phases, $U$ and Mo appeared to be related to Fe and Mn oxides. These relationships, which can be expected to vary both temporally and spatially, played important roles in the cycling of $U$ and Mo in the sediments. Some of the $\mathrm{U}$ and a larger fraction of the Mo that are removed to the solid phase may have been recycled within the sediments.

\subsection{Nondiffusive Solute Transport}

Nondiffusive transport by sediment irrigation is important to this study for two reasons. First, it may enhance the exchange of solutes between bottom water and sediments. If this is the case, the role of nondiffusive processes for RSM transport must 
be evaluated for the significance of shallow water sediments to the marine budgets of these elements to be considered. Second, reactions in and around infaunal burrows may affect transport by irrigation, and the analysis of these reactions may lead to insights on the diagenesis of RSM. Here, we apply the model of equations 4-7 to the analysis of sediment irrigation at the Hingham Bay site by using the nonreactive tracer, $\mathrm{Br}^{-}$, to determine transport rates, and then applying the irrigation model to reactive solutes.

In this study, we do not have pore water profiles of $\mathrm{Br}^{-}$at the end of chamber deployments (Martin and Banta, 1992; Martin and Sayles, 2004), but only changing Br concentrations with time in the chamber overlying water (Fig. 8). Thus, we have no information on the depth-dependence of $\alpha$ (Equation 4). In the absence of this information, we have assumed a simple depth-dependence for $\alpha_{\mathrm{Br}}$ : constant from 0-8 cm below the interface, in the region above the zone of high $\mathrm{H}_{2} \mathrm{~S}$ concentrations, and zero below that. The values derived from this assumption are applied to other solutes. In Figure 8, we compare the fits to $\mathrm{Br}^{-}$concentration vs. time data using this form of $\alpha$ to those made assuming $\alpha$ decreases exponentially with increasing depth below the interface. In the latter case, $\alpha$ remains nonzero well into the zone of high $\mathrm{H}_{2} \mathrm{~S}$ concentrations.

The $\mathrm{Br}^{-}$model was applied to eight benthic chamber deployments between June 2001 and June 2004, and in five cases the model explained the results quite well (see Fig. 8 caption). The seasonal distribution of $\alpha$ values is shown in the top panel of Figure 4. In the figure, the open symbols in the $\alpha$ panel refer to chamber 3 from June 2001 (June 2001ch3) and May 2002 chambers, in which the model did not fit the data well. The observation of maximum $\alpha$ values in early summer agrees with the additional observation 
of maximal differences between total and diffusive fluxes of $\mathrm{NH}_{4}{ }^{+}$and $\mathrm{TCO}_{2}$ during the same time period. The large difference between diffusive and total $\mathrm{TCO}_{2}$ fluxes in January cannot be explained by irrigation.

We assess the importance of nondiffusive transport to sediment-seawater exchange of $U$ and Mo by comparing diffusive fluxes, calculated from pore water profiles, to fluxes determined using in situ benthic flux chambers. In order to gain insight into the processes that control nondiffusive solute exchange, we compare results for the metals to similar data for $\mathrm{TCO}_{2}$ and $\mathrm{NH}_{4}^{+}$, the most abundant dissolved products of organic matter oxidation at this site. We carry out our analysis at the sampling times when $\mathrm{Br}^{-}$tracer data were adequately explained by our irrigation model. For $\mathrm{U}$ and Mo, these times are June 2001ch4, January 2002ch4, and October 2002ch4. Pore water data used in the analysis come from January, June, and October 2001. Thus, we have assumed that inter-annual differences between pore water profiles in January and October are small compared to their large scale features. At each time point, we use the composite profiles resulting from fits of our RSM pore water model to represent the pore water profiles (Figure 7). For $\mathrm{TCO}_{2}$ and $\mathrm{NH}_{4}{ }^{+}$, we use the flux chamber experiments noted above and June 2004ch4; pore water data collected at the same time as the corresponding flux chamber experiments were used for these calculations. In the case of $\mathrm{TCO}_{2}$ and $\mathrm{NH}_{4}{ }^{+}$, the January 2002ch4 flux chamber experiment gave anomalously large fluxes that could not be explained by nondiffusive transport; the additional $\mathrm{TCO}_{2}$ and $\mathrm{NH}_{4}{ }^{+}$most likely came from reaction of material on the sediment surface. While we plot these data with the rest, we omit them from calculations of averages. 
Nondiffusive solute transport is a major contributor to sediment-seawater exchange at the Hingham Bay site, particularly in the summer (Fig. 9A). If nondiffusive transport was negligible, then the ratio of the chamber flux, which represents the total flux, to the diffusive flux calculated from the pore water profiles would be equal to one. As nondiffusive transport becomes more important, this ratio will become greater than one. The ratios of chamber flux to diffusive flux average $3.3 \pm 1.1$ for $\mathrm{TCO}_{2}, 1.9 \pm 0.4$ for $\mathrm{NH}_{4}{ }^{+}, 4.8 \pm 3.9$ for $\mathrm{U}$, and $24 \pm 11$ for Mo.

In order to explore the reasons for the differences between the solutes, we use the model of equations 6 and 7 to determine the depth-averaged "reaction parameter", $f_{\mathrm{i}}$, for $\mathrm{TCO}_{2}, \mathrm{NH}_{4}{ }^{+}, \mathrm{U}$, and Mo. The values of $f_{\mathrm{i}}$ are shown in Figure 9B. At every time point, $f_{\mathrm{NH} 4}<f_{\mathrm{TCO} 2}$. Accounting for the variation in the calculation (excluding January 2002) $f_{\mathrm{TCO} 2}$ is indistinguishable from one $(1.17 \pm 0.30)$, while $f_{\mathrm{NH} 4}$ is slightly less than one $(0.69 \pm 0.40)$. This result is consistent with the pore water profiles of the two solutes (Fig. 2), which show that, at some times of year, there is an apparent zone of net $\mathrm{NH}_{4}{ }^{+}$removal at and just below the sediment water interface, while no such zone is apparent for $\mathrm{TCO}_{2}$. $\mathrm{NH}_{4}{ }^{+}$removal may be by adsorption to solids or denitrification. An analogous zone may occur along the walls of burrows that are exposed to oxygenated bottom water during flushing events. $f_{\mathrm{U}}$ is similar to that for $\mathrm{TCO}_{2}$, but more variable (1.29 \pm 0.73$)$. If $\mathrm{TCO}_{2}$ represents a solute whose irrigation flux is not affected by reactions in and around burrows at this site, then $\mathrm{U}$ appears to behave conservatively during irrigation as well. $f_{\mathrm{U}}$ depends directly on the value of the diffusion coefficient for U. If we have overestimated the $\mathrm{U}$ diffusion coefficient, then we have underestimated $f_{\mathrm{U}}$ (see section 3.1). A value of $f_{\mathrm{U}}$ significantly greater than one would imply enhanced $\mathrm{U}$ uptake due to reactions in and 
around burrows. Two possibilities are: (1) coprecipitation with Fe and/or Mn oxides, which may form in burrow walls when dissolved Fe and Mn encounter oxygenated burrow water (Aller and Aller, 1986), or (2) removal of U by processes similar to those that drive $\mathrm{U}$ loss from pore water to solids in bulk sediments. In contrast to $\mathrm{U}, f_{\mathrm{Mo}}$ is both

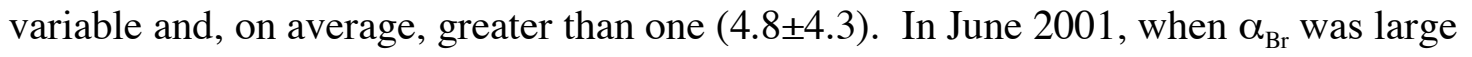
$\left(0.5 \mathrm{y}^{-1}\right), f_{\text {Mo }}$ was 0.25 , a value that indicates that the chamber flux from overlying water into the sediments was much smaller than the calculated transport-only flux. An explanation for this observation is that exposure to oxygenated water may have caused oxidative release of Mo to solution near burrows, reducing the burrow/pore water Mo concentration gradient. At the two time points when $\alpha_{\mathrm{Br}}$ was small (October 2002, January 2002: $\left.\alpha_{\mathrm{Br}} \sim 0.03 \mathrm{y}^{-1}\right), f_{\mathrm{Mo}}$ was very large $(5.3-8.8)$. Such a large value would occur if reactions at the burrow walls, similar to those described above for possible $U$ uptake, enhanced Mo uptake. Consistent with Mo pore water profiles, Mo can undergo both release from and uptake to solids, with the balance between the two processes depending on small changes in the environment. The very large swings in $f_{\text {Mo }}$ are most likely due to the large difference between $[\mathrm{Mo}]_{\mathrm{bw}}(\sim 110 \mathrm{nM})$ and $[\mathrm{Mo}]_{\infty}(\sim 10 \mathrm{nM})$. Because of this large difference, potential irrigation fluxes are very large.

\subsection{Accumulation of authigenic $U$ and Mo}

The sedimentary solids at the Hingham Bay site have $7.5 \times 10^{-4} \mathrm{~mol} / \mathrm{g}_{\text {sed }}(\sim 42,000$ $\mathrm{ppm}) \mathrm{Fe}$ and $1.1 \times 10^{-5} \mathrm{~mol} / \mathrm{g}_{\text {sed }}(600 \mathrm{ppm}) \mathrm{Mn}$, and there is a distinct maximum in solid phase $\mathrm{Mn}$ concentration at the sediment-water interface and a less readily apparent $\mathrm{Fe}$ maximum (Fig. 10). Mo tends to have higher concentrations in the upper $1 \mathrm{~cm}$ than in the 
sediments immediately below $1 \mathrm{~cm}$, presumably due to adsorption to Mn oxides in surface sediments, but there is little trend discernible in solid phase U over this interval. Below $1 \mathrm{~cm}, \mathrm{U}$ increases rapidly from an average of 1.12 to $1.6\left(\mathrm{x} 10^{-8}\right) \mathrm{mol} / \mathrm{g}_{\text {sed }}$ $(2.67 \pm 0.05$ to $3.8 \pm 0.3 \mathrm{ppm})$ at $10-15 \mathrm{~cm}$. Mo also has a zone of rapid increase, starting at $\sim 2.5 \mathrm{~cm}$ and continuing to $10 \mathrm{~cm}$. The Mo increase is from 1.5 to $4.2\left(\mathrm{x} 10^{-8}\right) \mathrm{mol} / \mathrm{g}_{\text {sed }}$ ( $1.4 \pm 0.1$ to $4.0 \pm 0.6 \mathrm{ppm})$. These zones of increasing solid phase concentration correspond closely to those that would be predicted from the pore water profiles (see sections 4.3 and 4.4). Therefore, the solid phase profiles are consistent with the accumulation of $4.6 \times 10^{-8} \mathrm{~mol} / \mathrm{g}_{\text {sed }}(1.1 \pm 0.4 \mathrm{ppm})$ of authigenic $\mathrm{U}$ and $2.8 \times 10^{-8} \mathrm{~mol} / \mathrm{g}_{\text {sed }}$ $(2.7 \pm 0.6 \mathrm{ppm})$ of authigenic Mo. Because of the complicated recent sedimentation history of the site, we cannot make rigorous predictions of the concentrations of authigenic $U$ and Mo that would result from the measured loss rates from solution. Instead, we note first that the average sedimentation rate from 1978-2000 was $0.6 \mathrm{~cm} \mathrm{y}^{-1}$. At this rate, over $13 \mathrm{~cm}$ of sediment would have accumulated during that time span; a $13 \mathrm{~cm}$ sediment layer includes the region over which $\mathrm{U}$ and Mo increase in concentration. We assume that the processes removing $\mathrm{U}$ and Mo from solution have not changed significantly over that period, so that the loss rates from solution $\left(F_{\text {loss }}\right)$ can be calculated from: (a) the downward diffusive flux of the RSM at $\mathrm{x}=\mathrm{x}_{\mathrm{p}}$ (Table 3), or (b) the average flux into the sediments measured by the benthic flux chambers (Table 4). We then calculate the predicted authigenic RSM concentration $\left(C_{\text {auth }}\right)$ as a function of the sedimentation rate $(\mathrm{w})$, and sediment density $\left(\rho_{\mathrm{s}}\right)$ :

$$
C_{\text {auth }}\left(\frac{n m o l}{g_{\text {sed }}}\right)=\frac{F_{\text {loss }}\left(\frac{\mathrm{pmol}}{\mathrm{cm}^{2} \mathrm{y}}\right) \times 10^{-3}}{\rho_{s}(1-\phi) w} \quad \text { (Equation 8) }
$$


The result of this calculation is shown in Figure 11. Although there are clearly large uncertainties associated with the calculation, the ranges of observed authigenic $U$ and Mo coincide with the combination of loss rates from benthic flux chamber determinations and the average sedimentation rate over the 1978-2000 time period. Authigenic U and Mo concentrations predicted using diffusive fluxes determined from pore water profiles are substantially lower.

\subsection{Importance of shallow sediments for marine budgets of $U$, Re, and Mo}

Accumulation rates of $\mathrm{U}, \mathrm{Mo}$, and Re have been determined at several locations with water depths less than $1000 \mathrm{~m}$, including sites on both the Pacific (Zheng et al., 2000, 2002a; McManus et al., 2005; Morford and Emerson, 1999; Nameroff et al., 2002; Morford et al., 2005) and Atlantic (Zheng et al., 2002a; Sundby et al., 2004; this work) margins. Studies on the Pacific margin have included several locations in the California borderlands with low bottom water $\mathrm{O}_{2}$ levels. However, none of the studies prior to this one have included sites at water depths less than $100 \mathrm{~m}$ and few studies have been done at sites with extremely high organic matter oxidation rates (Table 5). The study site examined in this work is very shallow $(5 \mathrm{~m})$ and has a very high organic matter oxidation rate $\left(880 \mu \mathrm{mol} \mathrm{cm} \mathrm{cm}^{-2}\right)$. Therefore, it serves as an "end-member" shallow water sediment site, and differences between our results and the patterns found in earlier studies can serve as a guide for the importance of shallow-water, coastal sediments to the marine budgets of U, Mo, and Re.

The first result from the Hingham Bay site that stands out is the importance of sediment irrigation to the accumulation of RSMs. When we used diffusive fluxes 
calculated from pore water profiles to estimate the accumulation of RSM, we obtained similar rates to those found in the Santa Barbara Basin (Zheng et al., 2000), the NW U.S. margin (Morford et al., 2005), and the Laurentian Trough (Sundby et al., 2004). However, we found that the nondiffusive fluxes of $U$ and Mo greatly enhanced the calculated uptake of these metals and that the authigenic metal concentrations predicted from benthic chamber fluxes matched observed solid phase concentrations. The authigenic $U$ and Mo accumulation rates determined with benthic chamber fluxes at the Hingham site are the largest that have been reported to date (Tables 4 and 5). Since sediment irrigation begins to be important at benthic organic matter oxidation rates of $\sim 70 \mu \mathrm{mol} \mathrm{C} \mathrm{cm}{ }^{-2} \mathrm{y}^{-1}$ (Jahnke, 2001), it will be important to include the contribution of nondiffusive transport to RSM uptake in shallow water sediments.

In addition, this study confirms recent work showing that, if the rate of organic matter oxidation is sufficiently high, rapid accumulation of RSMs can occur even when the bottom water $\mathrm{O}_{2}$ concentration is high (McManus et al., 2005; Sundby et al., 2004). At the Hingham Bay site, with bottom water $\mathrm{O}_{2}$ concentrations ranging from 240-380 $\mu \mathrm{M}$, diffusive uptake of Re was similar to that measured on the NW Pacific margin, where bottom water $\mathrm{O}_{2}$ was 25-100 $\mu \mathrm{M}$ (Morford et al., 2005). Note that our results may underestimate uptake of Re at Hingham Bay, since we do not include irrigation-driven uptake for Re. Total uptake of $U$ and Mo was similar to, or greater than, rates measured in the Santa Barbara Basin (Zheng et al., 2000, 2002a). The $\mathrm{O}_{2}$ penetration depth at Hingham was similar to those measured at many other sites $(0.2-0.6 \mathrm{~cm})$, but the supply of labile organic matter was great enough to fuel the rapid anoxic diagenesis that appears to control RSM uptake. 
There was uptake of $\mathrm{U}, \mathrm{Re}$ and Mo at all times of year. Therefore, at least at a site with rapid organic matter oxidation and sulfidic pore waters throughout the year, potential recycling of RSM with deeper $\mathrm{O}_{2}$ penetration in the winter did not occur. This result strengthens the case for an important role for shallow-water sediments in the marine budgets of U, Mo, and Re. In future work, it will be important to continue to fill the large gap in RSM uptake data that remains by measuring their accumulation in margin sediments with organic matter oxidation rates in the range from $200-850 \mu \mathrm{mol} \mathrm{C}$ $\mathrm{cm}^{-2} \mathrm{y}^{-1}$

\section{CONCLUSION}

At the Hingham Bay site, the input of $U$ and $R e$ to sediments is via solute transport; however, in surface sediments there is a net release of Mo from the solid phase to pore waters that increases from January to October, most likely related to Mo release during Mn and possibly Fe oxide reduction. Removal of Re to the solid phase begins at the sediment-water interface, and the rate of removal increases seasonally as the redox horizons become shallower. U removal is deeper than that of Re during the summer and fall. The depth of removal for Mo is deeper than either $U$ or Re and increases systematically from January to October, although the depth at which Mo reaches its minimum concentration is seasonally unchanged and apparently related to the appearance of $\mathrm{H}_{2} \mathrm{~S}$ in pore waters. In situ experiments with benthic chambers that reached low chamber $\mathrm{O}_{2}$ concentrations suggest that $\mathrm{Mo}$ and $\mathrm{U}$ are associated with $\mathrm{Mn}$ and Fe oxides 
in surface sediments and can be released on short timescales when Mn and Fe oxides are reduced.

Comparisons between calculated and in situ measured diffusive fluxes suggest that nondiffusive solute transport is a major contributor to sediment-seawater exchange at the Hingham Bay site. U appears to behave conservatively during irrigation whereas Mo appears to undergo both release from and uptake to burrow walls.

Calculations using the total flux from benthic chamber measurements and the estimated current sedimentation rate accurately predict the measured authigenic $\mathrm{U}$ and Mo sediment concentrations. The consistent direction of fluxes into sediments for $\mathrm{U}$, Mo and Re points to coastal sediments with high organic matter oxidation rates and sulfidic pore waters as a sink for these RSM regardless of season. Reducing shallow sediments are comparable to or greater than continental margin sediments as a sink for $\mathrm{U}, \mathrm{Re}$ and Mo. The rapid, seasonal cycling of $\mathrm{Mn}$ and Fe oxides in shallow sediments has the potential to complicate the accumulation of $U$ and Mo since they appear to co-cycle with these oxides. However, at the Hingham Bay site, which had rapid organic matter oxidation and sulfidic pore waters throughout the year, recycling of RSMs with deeper $\mathrm{O}_{2}$ penetration in the winter did not occur. Re does not appear to be associated with Mn or Fe oxides, which suggests that reducing shallow sediments present a simple sink for authigenic Re that is comparable to continental margin sediments. Although quantifying the global area of fine-grained, reducing shallow sediments may be problematic, these sediments are a sink for these RSM and should be included in any global mass balance of these elements. 
Acknowledgements The authors would like to thank the U.S. Coast Guard and the operators of the USGS boat, R/V Raphael, for their help with sample collection. Dann Blackwood, Lary Ball, and Michael Casso provided invaluable field assistance and skilled SCUBA diving. The authors would also like to thank Joanne Goudreau who was indispensable during benthic chamber preparation, deployment, and recovery and who carried out many chemical analyses. JLM acknowledges the ICP-MS expertise provided by Dave Schneider of the WHOI Plasma Facility. We appreciate the financial support from the National Science Foundation (OCE-0220892). Funding for this work was also provided to JLM by the Postdoctoral Scholar Program at WHOI courtesy of the Cabot Marine Environmental Science Fund and the J. Seward Johnson Fund. Financial support to IMK was given by The Swedish Foundation for International Cooperation in Research and Higher Education. Thought provoking comments that improved this manuscript were supplied by John Crusius, Tim Shaw and two anonymous reviewers. 


\section{References}

Adelson J.M., Helz G.R. and Miller C.V. (2001) Reconstructing the rise of recent coastal anoxia; molybdenum in Chesapeake Bay sediments. Geochim. Cosmochim. Acta 65(2), 237-252.

Aller J.Y. and Aller R.C. (1986) Evidence for localized enhancement of biological activity associated with tube and burrow structures in deep-sea sediments at the HEBBLE site, western North Atlantic. Deep-Sea Research 33, 755-790.

Aller R. C. (1994). The sedimentary Mn cycle in Long Island Sound: Its role as intermediate oxidant and the influence of bioturbation, $\mathrm{O}_{2}$, and $\mathrm{C}_{\text {org }}$ flux on diagenetic reaction balances. Journal of Marine Research 52, 259-295.

Aller R.C. (2001) Transport and reactions in the bioirrigated zone. In: The Benthic Boundary Layer: Transport Processes and Biogeochemistry. B.P. Boudreau and B.B. Jorgensen. New York, NY, Oxford University Press: 269-301.

Anderson R.F. (1982) Concentration, vertical flux, and remineralization of particulate uranium in seawater. Geochim. Cosmochim. Acta 46, 1293-1299.

Anderson L. A. and Sarmiento J. L. (1994) Redfield ratios of remineralization determined by nutrient data analysis. Global Biogeochemical Cycles 8(1), 65-80.

Anderson R.F., Kumar N., Mortlock R.A., Froelich P.N., Kubik P., Dittrich-Hannen B., and Suter M. (1998) Late-Quaternary changes in productivity of the Southern Ocean. Journal of Marine Systems 17, 497-514.

Andrews D. and Bennett A. (1981) Measurements of diffusivity near the sediment-water interface with a fine-scale resistivity probe. Geochimica et Cosmochimica Acta $\mathbf{4 5}$, 2169-2175.

Archer D. E., Morford J. L. and Emerson S. R. (2002) A model of suboxic sedimentary diagenesis suitable for automatic tuning and gridded global domains. Global Biogeochemical Cycles 16(1), 10.1029/2000GB001288.

Barnes C. E. and Cochran J. K . (1993) Uranium geochemistry in estuarine sediments: Controls on removal and release processes. Geochim. Cosmochim. Acta 57, 555-569.

Berner R. A. (1980). Early Diagenesis: A Theoretical Approach. Princeton, N.J., Princeton University Press.

Bertine K.K. and Turekian K. (1973) Mo in marine deposits. Geochim. Cosmochim. Acta 37, 1415-1434.

Bothner M., ten Brink M.B. and Manheim F. (1998) Metal concentrations in surface sediments of Boston Harbor - changes with time. Marine Environmental Research 45(2), 127-155.

Boudreau B. P. (1984) On the equivalence of nonlocal and radial-diffusion models for porewater irrigation. Journal of Marine Research 42, 731-735.

Breckel E.J., Emerson S. and Balistrieri L. (2005) Authigenesis of trace metals in energetic tropical shelf environments. Continental Shelf Research 25, 1321-1337.

Briggs P. and Meier A. (1999) The determination of forty-two elements in geological materials by inductively coupled mass spectrometry. U.S. Geological Survey Open File Report 99-166.

Calvert S. and Pedersen T. (1993) Geochemistry of recent oxic and anoxic marine sediments: Implications for the geological record. Marine Geology 113, 67-88. 
Christensen J. P., Devol A. H., et al. (1984). Biological enhancement of solute exchange between sediments and bottom water on the Washington continental shelf. Continental Shelf Research 3, 9-23.

Church T.M., Sarin M.M., Fleisher M.Q. and Ferdelman T.G. (1996) Salt marshes: An important coastal sink for dissolved uranium. Geochim. Cosmochim. Acta 60(20), 3879-3887.

Cline J. (1969). Spectrophotometric determination of hydrogen sulfide in natural waters. Limnology and Oceanography 14(3), 454-458.

Colodner D. (1991) The Marine Geochemistry of Rhenium, Iridium and Platinum. Ph.D. Thesis, WHOI, pg. 276.

Colodner D., Sachs J., Ravizza G., Turekian K., Edmond J. and Boyle E. (1993) The geochemical cycle of rhenium: a reconnaissance. Earth Planet. Sci. Lett. 117, 205221.

Crusius J. and Thomson J. (2000) Comparative behavior of authigenic Re, U, and Mo during reoxidation and subsequent long-term burial in marine sediments. Geochim. Cosmochim. Acta 64(13), 2233-2242.

Crusius J., Calvert S.E., Pedersen T.F. and Sage D. (1996) Rhenium and molybdenum enrichments in sediments as indicators of oxic, suboxic and anoxic conditions of deposition. Earth Planet. Sci. Lett. 145, 65-79.

Dean W., Gardner J., and Anderson R. (1994) Geochemical evidence for enhanced preservation of organic matter in the oxygen minimum zone of the continental margin of northern California during the late Pleistocene. Paleoceangr. 9, 47-61.

Dean W., Gardner J. V., and Piper D. Z. (1997) Inorganic geochemical indicators of glacial-interglacial changes in productivity and anoxia on the California continental margin. Geochim. Cosmochim. Acta 61, 4507-4518.

Duff M.C., Coughlin J.U. and Hunter D.B. (2002) Uranium co-precipitation with iron oxide minerals. Geochim. Cosmochim. Acta 66(20), 3533-3547.

Emerson S.R. Jahnke R., and D. Heggie (1984) Sediment-water exchange in shallow water estuarine sediments. Journal of Marine Research 42, 709-730.

Erickson B.E. and Helz G.R. (2000) Molybdenum(VI) speciation in sulfidic waters: Stability and lability of thiomolybdates. Geochim. Cosmochim. Acta 64(7), 11491158.

François R., Bacon M. P., Altabet M. A., and Labeyrie L. D. (1993) Glacial/Interglacial changes in sediment rain rate in the SW Indian sector of Subantarctic waters as recorded by ${ }^{230} \mathrm{Th},{ }^{231} \mathrm{~Pa}$, U and delta ${ }^{15} \mathrm{~N}$. Paleoceangr. 8, 611-629.

François R., Altabet M.Z., Yu E-F., Sigman D.M., Bacon M.P., Frank M., Bohrmann G., Bareille G., and Labeyrie L.D. (1997) Contribution of Southern Ocean surface-water stratification to low atmospheric $\mathrm{CO} 2$ concentrations during the last glacial period. Nature 389, 929-935.

Glibert P.L. and Loder T.C. (1977) Automated analysis of nutrients in seawater: A manual of techniques. Technical Report, Woods Hole Oceanographic Institution, Woods Hole, MA.

Hartnett H. E. and Devol A. H. (2003) Role of a strong oxygen-deficient zone in the preservation and degradation of organic matter: A carbon budget for the continental margins of northwest Mexico and Washington State. Geochim. Cosmochim. Acta, 67(2), 247-264. 
Helz G.R., Miller C.V., Charnock J.M., Mosselmans J.F.W., Pattrick R.A.D., Garner C.D. and Vaughan D.J. (1996) Mechanism of molybdenum removal from the sea and its concentration in black shales: EXAFS evidence. Geochim. Cosmochim. Acta 60(19), 3631-3642.

Jahnke, R.A. (2001) Constraining organic matter cycling with benthic fluxes. In B.P. Boudreau and B.B. Jorgensen, eds., The Benthic Boundary Layer: Transport Processes and Biogeochemistry, p. 302-319. Oxford University Press, New York, NY.

Kalnejais L. H. (2005). Mechanisms of Metal Release from Contaminated Coastal Sediments, Massachusetts Institute of Technology / Woods Hole Oceanographic Institution: 238.

Kato Y., Tanase M., Minami H. and Okabe S. (1995) Remobilization of transition elements in pore water of continental slope sediments. In Biogeochemical Processes and Ocean Flux in the Western Pacific (eds. H. Sakai and Y. Nozaki), Terra Scientific Publishing, pp 383-405.

Klinkhammer G.P. and Palmer M.R. (1991) Uranium in the oceans: where it goes and why. Geochim. Cosmochim Acta 55, 1799-1806.

Li Y. and Gregory S. (1974) Diffusion of ions in sea water and in deep-sea sediments. Geochim. Cosmochim. Acta 38, 703-714.

Libby S., Geyer R., et al. (2002). 2001 Annual water column monitoring report. Boston MA, Massachusetts Water Resources Authority.

Libby, S., Geyer R., et al. (2003). 2002 Annual water column monitoring report. Boston MA, Massachusetts Water Resources Authority.

Libby, S., Keller A., et al. (2004a). 2003 Annual water column monitoring report. Boston MA, Massachusetts Water Resources Authority.

Libby, S., Mansfield A., et al. (2004b). Semiannual water column monitoring report, February - June 2004. Boston MA, Massachusetts Water Resources Authority.

Manheim F.T. (1974) Molybdenum. In Handbook of Geochemistry (ed. K.H. Wedepohl), Springer-Verlag.

Manheim F. T., Dwight L., et al. (1974) Porosity, density, grain density, and related physical properties of sediments from the Red Sea drill cores. Initial Reports of the Deep Sea Drilling Project XXIII. R. B. Whitmarsh, Waser, O.E., Ross, D.A., et al.: 887-907.

Martin W.R. and Banta G.T. (1992) The measurement of sediment irrigation rates: A comparison of the $\mathrm{Br}^{-}$tracer and ${ }^{222} \mathrm{Rn} /{ }^{226} \mathrm{Ra}$ disequilibrium techniques. Journal of Marine Research 50, 125-154.

Martin W. R. and Sayles F. L. (2004). Organic matter cycling in sediments of the continental margin in the northwest Atlantic Ocean. Deep-Sea Research I 51, 457-489.

Martin W. R. and Sayles F. L. (1987). Seasonal cycles of particle and solute transport processes in nearshore sediments: ${ }^{222} \mathrm{Rn} /{ }^{226} \mathrm{Ra}$ and ${ }^{234} \mathrm{Th} /{ }^{238} \mathrm{U}$ disequilibrium at a site in Buzzards Bay, MA. Geochim. Cosmochim. Acta 51, 927-943.

McDuff R. E. and Ellis R. A. (1979) Determining diffusion coefficients in marine sediments: a laboratory study of the validity of resistivity techniques. American Journal of Science 279, 666-675.

McKee B.A., DeMaster D.J. and Nittrouer C.A. (1987) Uranium geochemistry on the Amazon shelf: Evidence for uranium release from bottom sediments. Geochim. Cosmochim. Acta 51, 2779-2786. 
McManus J., Berelson W.M., Klinkhammer G.P., Hammond D.E. and Holm C. (2005) Authigenic uranium: relationship to oxygen penetration depth and organic carbon rain. Geochim. Cosmochim. Acta 69(1), 95-108.

Morford J.L and Emerson S. (1999) The geochemistry of redox sensitive trace metals in sediments. Geochim. Cosmochim. Acta 63, 1735-1750.

Morford J.L., Kalnejais L., Martin W., Francois R. and Karle I.-M. (2003) Sampling marine pore waters for $\mathrm{Mn}, \mathrm{Fe}, \mathrm{U}, \mathrm{Re}$ and Mo: modifications on diffusional equilibration thin film gel probes. Journal of Experimental Marine Biology and Ecology 285-286, 85-103.

Morford J.L., Emerson S.R., Breckel E.J. and Kim S.H. (2005) Diagenesis of oxyanions (V, U, Re and Mo) in pore waters and sediments from a continental margin. Geochim. Cosmochim. Acta 69(21), 5021-5032.

Nameroff T. J., Calvert S. E. and Murray J. W. (2004) Glacial-interglacial variability in the eastern tropical North Pacific oxygen minimum zone recorded by redox-sensitive trace metals. Paleoceanography 19, 10.1029/2003PA000912.

Nameroff T. J., Balistrieri L. S. and Murray J. W. (2002) Suboxic trace metal geochemistry in the eastern tropical North Pacific. Geochim. Cosmochim. Acta 66(7), 1139-1158.

O'Sullivan D. W. and Millero F. J. (1998). Continual measurement of the total inorganic carbon in surface seawater. Marine Chemistry 60, 75-83.

Press W.H., Flannery B.P., Teukolsky S.A. and Vetterling W.T. (1986) Numerical Recipes: The Art of Scientific Computing. Cambridge, U.K., Cambridge University Press.

Rodushkin I. and Ruth T. (1997) Determination of trace metals in estuarine and seawater reference materials by high resolution inductively coupled plasma mass spectrometry. J. Anal. At. Spectrom. 12, 1181-1185.

Rosenthal Y., Boyle E. A., Labeyrie L., and Oppo D. (1995) Glacial enrichments of authigenic $\mathrm{Cd}$ and $\mathrm{U}$ in Subantarctic sediments: A climatic control on the elements' ocean budget? Paleoceanography 10, 395-413.

Sayles F.L. and Dickinson W.H. (1991) The ROLAI2D lander: a benthic lander for the study of exchange across the sediment-water interface. Deep-Sea Research 38(5), 505529.

Sayles F. L. and Martin W. R. (1995) In situ tracer studies of solute transport across the sediment-water interface at the Bermuda Time Series site. Deep-Sea Research I 42, 31-52.

Sayles F. L., Martin W. R., Chase Z. and Anderson R. F. (2001) Benthic remineralization and burtial of biogenic $\mathrm{SiO}_{2}, \mathrm{CaCO}_{3}$, organic carbon, and detrital material in the Southern Ocean along a transect at $170^{\circ}$ West. Deep-Sea Research II 48, 4323-4383.

Shaw T.J., Gieskes J.M. and Jahnke R.A. (1990) Early diagenesis in differing depositional environments: The response of transition metals in pore water. Geochim. Cosmochim. Acta 54, 1233-1246.

Sundby B., Martinez P. and Gobeil C. (2004) Comparative geochemistry of cadmium, rhenium, uranium, and molybdenum in continental margin sediments. Geochim. Cosmochim. Acta 68(11), 2485-2493.

Taylor D. I. (2005). Patterns of wastewater, river, and non-point source loadings to Boston Harbor, 1995-2003. Boston, MA, Massachusetts Water Resources Authority. 
Vorlicek T.P. and Helz G.R. (2002) Catalysis by mineral surfaces: Implications for Mo geochemistry in anoxic environments. Geochim. Cosmochim. Acta 66(21), 3679-3692. Vorlicek T.P., Kahn M.D., Kasuya Y. and Helz G.R. (2004) Capture of molybdenum in pyrite-forming sediments: Role of ligand-induced reduction by polysulfides. Geochim. Cosmochim. Acta 68(3), 547-556.

Zheng Y., Anderson R.F., van Geen A. and Kuwabara J. (2000) Authigenic molybdenum formation in marine sediments: A link to pore water sulfide in the Santa Barbara Basin. Geochim. Cosmochim. Acta 64(24), 4165-4178.

Zheng Y., Anderson R.F., van Geen A. and Fleisher M.Q. (2002a) Remobilization of authigenic uranium in marine sediments by bioturbation. Geochim. Cosmochim. Acta 66(10), 1759-1772.

Zheng Y., Anderson R.F., van Geen A. and Fleisher M.Q. (2002b) Preservation of particulate non-lithogenic uranium in marine sediments. Geochim. Cosmochim. Acta 66(17), 3085-3092. 
Table 1. Inputs for RSM model fits to composite pore water profiles.

\begin{tabular}{|c|c|c|c|c|c|c|c|c|c|c|c|}
\hline \multirow[t]{2}{*}{ Sampling } & \multirow{2}{*}{$\begin{array}{c}\text { Included } \\
\text { data }\end{array}$} & \multirow{2}{*}{$\begin{array}{l}\text { Omitted data } \\
\text { and rationale }\end{array}$} & \multicolumn{2}{|c|}{ Data used for model: } & \multirow[t]{2}{*}{$\chi^{2}$} & \multirow{2}{*}{$\frac{\chi^{2}}{n}$} & \multirow{2}{*}{$\begin{array}{l}D_{\mathrm{sw}} \\
\mathrm{cm}^{2} / \mathrm{y}\end{array}$} & \multicolumn{3}{|c|}{ Porosity } & \multirow{2}{*}{$\begin{array}{c}v-1 \\
\\
\text { (from the } \\
\text { Winsauer } \\
\text { relationship) }\end{array}$} \\
\hline & & & & $\begin{array}{l}\text { Range of std. } \\
\text { dev. at each } \\
\text { depth }\end{array}$ & & & & $\mathrm{a}$ & $\mathrm{b}$ & c & \\
\hline \multicolumn{12}{|l|}{$\mathbf{U}$} \\
\hline Jan 01 & $\begin{array}{c}\text { All } \\
\text { profiles }\end{array}$ & $\begin{array}{l}\text { Deepest } 2 \text { points: } \\
\text { inordinate effect }\end{array}$ & 12 & $0.62-1.77$ & 4.2 & 0.35 & 170 & .770 & .154 & .374 & 1.86 \\
\hline June 01 & $\begin{array}{c}\text { Cores } \\
1,2,3\end{array}$ & $\begin{array}{c}\text { Probe: } \\
\text { high at interface; } \\
\text { unusual slope }\end{array}$ & 25 & $\begin{array}{l}\text { av: } 0.5+/-0.4 \\
\quad(0.3-1.0)\end{array}$ & $\begin{array}{c}\mathrm{k}_{\mathrm{r}}=0: 48.6 \\
\mathrm{k}_{\mathrm{r}} \text { var: } 47.5\end{array}$ & $\begin{array}{l}1.9 \\
1.9\end{array}$ & 224 & .770 & .154 & .374 & 1.86 \\
\hline Oct 01 & $\begin{array}{l}\text { Cores } \\
2 \& 3\end{array}$ & $\begin{array}{c}\text { Core } 1: \text { burrow } \\
\text { Probe: possible Fe } \\
\text { oxidation }\end{array}$ & 21 & $\begin{array}{c}\text { av: } 0.6+/-0.4 \\
(0.5-1.5)\end{array}$ & 37.1 & 1.8 & 238 & .772 & .116 & .663 & 2.95 \\
\hline \multicolumn{12}{|l|}{$\operatorname{Re}$} \\
\hline Jan 01 & $\begin{array}{l}\text { Core } \\
1 \& 3 \\
\text { Part of } \\
\text { probe }\end{array}$ & $\begin{array}{c}\text { Core } 2: \text { high at } \\
\text { interface; unusual } \\
\text { slope } \\
\text { Probe: omit } 0.15 \text {, } \\
3.9,6 \mathrm{~cm}\end{array}$ & 16 & $\begin{array}{l}2.7+/-2.5 \\
(0.2-6.6)\end{array}$ & 154.4 & 9.6 & 158 & .770 & .154 & .374 & 1.86 \\
\hline June 01 & Parts of all & $\begin{array}{c}\text { Subsurface max in } \\
\text { core } 1 \text { and probe }\end{array}$ & 19 & $\begin{array}{c}2.2+/-1.3 \\
(0.7-4.1)\end{array}$ & 35.1 & 1.8 & 208 & .770 & .154 & .374 & 1.86 \\
\hline Oct 01 & $\begin{array}{l}\text { Cores } \\
2 \& 3 \\
\text { Part of } \\
\text { probe }\end{array}$ & $\begin{array}{l}\text { Core } 1: \text { burrow } \\
\text { Probe: } 5.0-10.0 \mathrm{~cm} \\
\text { possible Fe } \\
\text { oxidation }\end{array}$ & 28 & 5.9 & 15.0 & 0.53 & 221 & .772 & .116 & .663 & 2.95 \\
\hline \multicolumn{12}{|l|}{ Mo } \\
\hline Jan 01 & $\begin{array}{c}\text { All } \\
\text { profiles }\end{array}$ & $\begin{array}{l}\text { Deepest } 2 \text { points: } \\
\text { inordinate effect }\end{array}$ & 16 & $\begin{array}{c}5.8+/-7.6 \\
\text { (big: } 6.8 \mathrm{~cm} \text { ) }\end{array}$ & 16.6 & 1.0 & 170 & .770 & .154 & .374 & 1.86 \\
\hline June 01 & $\begin{array}{l}\text { Cores } \\
1,2,3\end{array}$ & $\begin{array}{l}\text { Probe: unusual peak } \\
\quad \text { in upper } 1 \mathrm{~cm}\end{array}$ & 27 & $\begin{array}{c}6.8+/-7.3 \\
\text { (used } 6.75, \text { all } \\
\text { pts) }\end{array}$ & 20.2 & 0.75 & 224 & .770 & .154 & .374 & 1.86 \\
\hline Oct 01 & $\begin{array}{l}\text { Cores } \\
2 \& 3\end{array}$ & $\begin{array}{l}\text { Core 1: burrow } \\
\text { Probe: possible } \\
\text { Fe oxidation }\end{array}$ & 22 & $\begin{array}{l}3.8+/-3.2 \\
(0.6-12.6)\end{array}$ & 22.0 & 1.0 & 238 & .772 & .116 & .663 & 2.95 \\
\hline
\end{tabular}


Table 2. Bioturbation mixing intensities in Hingham Bay as determined by excess ${ }^{234} \mathrm{Th}$ in sediments.

\begin{tabular}{|l|c|}
\hline Date & $\begin{array}{c}\text { Bioturbation mixing intensity } \\
\left(\mathrm{cm}^{2} \mathrm{y}^{-1}\right)\end{array}$ \\
\hline January 2002 & $3 \pm 1$ \\
\hline June 2004 & $20 \pm 3$ \\
\hline October 2002 & $24 \pm 5$ \\
\hline October 2003 & $6-15^{*}$ \\
\hline
\end{tabular}

*Note: The range in mixing intensity for October 2003 depends on how the instrument blank is subtracted from the data. 
Table 3. Best-fit model parameters for fitting the RSM composite profiles. The best values for the four variable parameters $\left(\mathrm{k}_{\mathrm{r}}, \mathrm{k}_{\mathrm{p}}, \mathrm{x}_{\mathrm{p}}\right.$ and $\left.\mathrm{C}_{\mathrm{eq}}\right)$ are presented along with the diffusive flux across the sediment-water interface $\left(\mathrm{F}_{0}\right)$, the diffusive flux calculated at the depth of removal $\left(\mathrm{F}_{\mathrm{xp}}\right)$, and their averages, standard deviations and percent relative deviations (\%RSD). The June $2001 \mathrm{U}$ data is modeled with both zero and non-zero $\mathrm{k}_{\mathrm{r}}$; however, the quality of the model fit is similar and the resulting diffusive fluxes differ by $\sim 30 \%$. When there is no additional source of RSM from release from solid phases in surface sediments $\left(\mathrm{k}_{\mathrm{r}}=0\right)$, then the flux across the sediment-water interface must be equivalent to the diffusive flux calculated at the depth of removal $\left(\mathrm{F}_{0}=\mathrm{F}_{\mathrm{xp}}\right)$.

Time

$$
\begin{array}{cccccc}
\mathrm{k}_{\mathrm{r}} & \mathrm{k}_{\mathrm{p}} & \mathrm{x}_{\mathrm{p}} & \mathrm{C}_{\mathrm{eq}} & \mathrm{U} & \mathrm{F} \\
\left(\mathrm{pmol} \mathrm{cm}{ }_{\mathrm{pw}} \mathrm{y}^{-1}\right) & \left(\mathrm{y}^{-1}\right) & (\mathrm{cm}) & \mathrm{Ro}(\mathrm{nM}) ; & \mathrm{F}_{0} & \mathrm{~F}_{\mathrm{xp}} \\
\left(\mathrm{pmol} \mathrm{cm} \mathrm{cm}^{-2} \mathrm{y}^{-1}\right) & \left(\mathrm{pmol} \mathrm{cm}^{-2} \mathrm{y}^{-1}\right)
\end{array}
$$

\section{Uranium}

Jan 01

0.0

133

0.00

2.59

$-1140$

$-1140$

Jun 01 a

0.0

208

1.71

3.28

$-493$

$-493$

Jun $01 \mathrm{~b}$

230

$198 \quad 1.45$

3.27

$-335$

$-632$

Oct 01

0.0

$13.5 \quad 1.00$

2.24

$-242$

$-242$

Average

$-620$

$-620$

\pm std dev (\%RSD)

$\pm 460(74 \%) \quad \pm 460(74 \%)$

\section{Rhenium}

Jan 01

0.0

$26.9 \quad 0.00$

13.6

$-1.42$

$-1.42$

Jun 01

0.0

$36.2 \quad 0.00$

13.8

$-1.87$

$-1.87$

Oct 01

0.0

$\begin{array}{ll}68.0 & 0.00\end{array}$

10.7

$-2.52$

$-2.52$

Average

$\pm \operatorname{std} \operatorname{dev}(\%$ RSD)

$-1.94$

$-1.94$

$\pm 0.55(28 \%) \quad \pm 0.55(28 \%)$

\section{Molybdenum}

\begin{tabular}{lcccccc} 
Jan 01 & 557 & 22.3 & 2.49 & 12.8 & -1000 & -2220 \\
Jun 01 & 727 & 103 & 4.23 & 10.3 & -541 & -3150 \\
Oct 01 & 866 & 1800 & 5.12 & 6.7 & 261 & -3310 \\
$\begin{array}{l}\text { Average } \\
\text { 土 std dev(\%RSD) }\end{array}$ & & & & & $\mathbf{- 4 3 0}$ & $\mathbf{- 2 8 9 0}$ \\
\hline
\end{tabular}


Table 4. Measured chamber fluxes for $U$ and Mo; Re was not measured in chamber samples. Note that both January 2002ch4 and September 2002ch4 were not oxygen-controlled.

\begin{tabular}{|c|c|c|c|c|}
\hline \multirow[b]{2}{*}{ Chamber } & \multicolumn{2}{|c|}{$\mathbf{U}$} & \multicolumn{2}{|c|}{ Mo } \\
\hline & $\mathrm{nmol} \mathrm{cm} \mathrm{cm}^{-2} \mathrm{~d}^{-1}$ & pmol cm $\mathrm{cm}^{-2} \mathrm{y}^{-1}$ & $\mathrm{nmol} \mathrm{cm} \mathrm{c}^{-2}$ & pmol $\mathrm{cm}^{-2} \mathrm{y}^{-1}$ \\
\hline Jan $02 \operatorname{ch} 4$ & -0.0036 & -1300 & -0.0630 & -23000 \\
\hline Jun $01 \operatorname{ch} 3$ & -0.0102 & -3720 & -0.0206 & -7520 \\
\hline Sep 02ch3 & -0.0035 & -1280 & -0.0214 & -7810 \\
\hline Sep 02ch4 & -0.0028 & -1030 & -0.0258 & -9420 \\
\hline $\begin{array}{c}\text { Average } \\
\text { ( } \pm \text { std dev) }\end{array}$ & $\begin{array}{l}-0.0050 \\
\pm 0.0035\end{array}$ & $\begin{array}{l}-1800 \\
\pm 1300\end{array}$ & $\begin{array}{l}-0.0330 \\
\pm 0.0200\end{array}$ & $\begin{array}{l}-11900 \\
\pm 7400\end{array}$ \\
\hline
\end{tabular}


Table 5. Compilation of $U, \operatorname{Re}$ and Mo fluxes into a range of locations. Positive fluxes are fluxes into sediments. For the Hingham Bay data, fluxes are presented from pore water profiles (PW) and from flux chambers (FC). Re was not measured in the flux chamber samples and is therefore not included for the latter value. Water depth, bottom water oxygen concentration $\left(\left[\mathrm{O}_{2}\right]_{\mathrm{bw}}\right)$, oxygen penetration depth into the sediments $\left(\mathrm{O}_{2, \text { pen }}\right)$, organic carbon oxidation rate, and sediment accumulation rate are compiled from the cited literature and references therein. Southern basins from the California margin include Tanner, Catalina, San Pedro, Santa Monica and San Clemente basins. Santa Barbara Basin is listed separately.

\begin{tabular}{|c|c|c|c|c|c|c|c|c|}
\hline Location & $\begin{array}{l}\text { Water } \\
\text { depth } \\
\text { (m) }\end{array}$ & $\begin{array}{l}{\left[\mathbf{O}_{2}\right]_{\mathrm{bw}}} \\
(\mu \mathrm{M})\end{array}$ & $\begin{array}{l}\mathbf{O}_{2, \text { pen }} \\
\text { (cm) }\end{array}$ & $\begin{array}{l}C_{\text {org }} \text { oxidation } \\
\text { rate } \\
\left(\mu \mathrm{mol} \mathrm{cm}{ }^{-2} \mathrm{y}^{-1}\right)\end{array}$ & $\begin{array}{l}\text { Sediment } \\
\text { acc rate } \\
\left(\mathrm{g} \mathrm{cm}^{-2} \mathrm{y}^{-1}\right)\end{array}$ & $\begin{array}{l}\text { RSM Fluxes } \\
\left(\mathrm{nmol} \mathrm{cm}^{-2} \mathrm{y}^{-1}\right) \\
U\end{array}$ & $\mathbf{R e}$ & Mo \\
\hline Hingham Bay, $\mathrm{MA}^{\mathrm{a}}$ & 5 & $240-380$ & $0.2-0.6$ & 880 & 0.054 & $\begin{array}{l}\text { PW: } 0.2-1.1 \\
\text { FC: } 1.0-3.7\end{array}$ & $1.4-2.5 \times 10^{-3}$ & $\begin{array}{l}2.2-3.3 \\
7.5-22\end{array}$ \\
\hline Laurentian Trough $^{\mathrm{b}}$ & $331-455$ & & $0.4-0.8$ & $55-165$ & $0.03-0.3$ & $0.17-0.76$ & $1.2-2.4 \times 10^{-3}$ & $0.26-4.5$ \\
\hline Mid-Atlantic Bight $^{\mathrm{d}}$ & $500-2000$ & $190-270$ & & $12-200$ & $0.03-0.04$ & $0.07-0.27$ & & \\
\hline \multicolumn{9}{|l|}{ California Margin } \\
\hline Central Margin ${ }^{\mathrm{c}, \mathrm{d}, \mathrm{e}}$ & $670-3595$ & $18-133$ & $0.2-2.9$ & $26-88$ & $0.004-0.01$ & $0.05-0.40$ & & \\
\hline Southern basins $^{\mathrm{e}}$ & $896-3707$ & $8-132$ & $0.16-2.9$ & $15-73$ & $0.003-0.03$ & $0.02-0.43$ & & \\
\hline S.Barbara Basin & $340-590$ & $3-25$ & & $230^{\mathrm{d}}$ & $0.065-0.24$ & $0.6-1.9^{\mathrm{d}}$ & & $0.5-13^{f}$ \\
\hline NW US Margin ${ }^{\mathrm{g}}$ & $100-2000$ & $25-100$ & $0.3-0.9$ & $15-730^{h}$ & $0.03-0.04$ & $0.06-0.1$ & $1.0-2.9 \times 10^{-3}$ & \\
\hline
\end{tabular}

a. This work; b. Sundby et al. (2004); c. Klinkhammer and Palmer (1991); d. Zheng et al. (2002a); e. McManus et al. (2005); f. Zheng et al. (2000); g. Morford and Emerson (1999), Morford et al. (2005); h. Hartnett and Devol (2003). 


\section{FIGURE CAPTIONS}

Figure 1: Location of the Hingham Bay site in southeastern Boston Harbor. The location of the effluent outfall $15.2 \mathrm{~km}$ offshore in Massachusetts Bay is included for reference.

Figure 2: Pore water $\mathrm{NH}_{4}{ }^{+}$and $\mathrm{TCO}_{2}$ concentration data from 2001 and 2002. In each of the four concentration versus depth plots, a representative core is illustrated from each time point. Two or three cores were sampled at each time, and when three cores were analyzed, the third core was the control core for the gel probe study as described in the methods section. The profiles showed little spatial variability. All three cores are shown in the $\mathrm{NH}_{4}{ }^{+}$versus $\mathrm{TCO}_{2}$ concentration plots from January and September 2002.

Figure 3: Concentration versus time in overlying water in the flux chambers. Filled symbols denote "standard" flux chambers, while open symbols denote " $\mathrm{O}_{2}$ controlled" chambers. Lines illustrate the time range of the data used to calculate fluxes. In the case of $\mathrm{O}_{2}$-controlled chambers, fluxes are calculated from the difference between a "steady-state" $\mathrm{O}_{2}$ value and bottom water $\left[\mathrm{O}_{2}\right]$ (see text). Figures 3A, B and C represent winter, late spring/early summer and early fall deployments.

Figure 4: The top panel shows values of the irrigation rate parameter ( $\alpha$, see text) derived from $\mathrm{Br}^{-}$loss from the overlying water in flux chambers. The three lower panels show fluxes across the sediment water interface in $\mu \mathrm{mol} \mathrm{cm} \mathrm{y}^{-1}$. Fluxes of $\mathrm{NH}_{4}^{+}$ and $\mathrm{TCO}_{2}$ are directed out of the sediments, while $\mathrm{O}_{2}$ fluxes are directed into the 
sediments. Fluxes calculated from both the pore water gradient across the sedimentwater interface (open triangles) and in situ flux chambers (filled circles) are shown for $\mathrm{TCO}_{2}$ and $\mathrm{NH}_{4}{ }^{+}$. For the pore water-based fluxes, each symbol is the average flux from two or three cores taken at a given time point. The flux chamber values are average values from deployments at the same time of year, but not always in the same year; therefore, they include inter-annual as well as small-scale spatial variability. Only one flux chamber measurement was made in January and resulted in large difference between direct and diffusive fluxes despite an apparent absence of irrigation. This anomalous result could be caused by spatial heterogeneity, as there was only a single January benthic flux chamber deployment, or it may have been the result of reactions at the sediment surface not resolved by pore water profiles.

Figure 5: Pore water data from the Hingham Bay site at three times of year in 2001 and 2002. When more than one profile was obtained at a given time point, results were averaged and the error bar is the standard deviation, indicating small-scale spatial variability. The seasonal shoaling of the appearance of dissolved $\mathrm{Fe}^{2+}$ was more pronounced in 2002 than in 2001.

Figure 6: Pore water trace metal profiles from 2001. Profiles from sectioned and centrifuged cores are shown with open symbols, whereas profiles from gel probe equilibrations, including gel sections sampled above the sediment-water interface, are shown by + symbols. Core $\# 3$ was sectioned $\sim 24$ hours after collection, and the similarity among profiles for cores 1,2 and 3 gives no indication that core \#3 profiles were affected by the delay. In June, the gel probe profile has elevated 
values of $\mathrm{Mn}, \mathrm{U}$, and Mo near the sediment-water interface and a pronounced subsurface maximum in Re that coincides with a smaller maximum in a sectioned core profile. Since early summer is the period of maximum sediment irrigation, the probe core may have been affected by oxidation in the vicinity of an infaunal burrow. In October, the gel probe profile shows elevated values of Fe and RSMs, particularly between $\sim 2-10 \mathrm{~cm}$, high values of RSMs in overlying water and visible discoloration on the gel sections and on the probe. These features are most likely due to exposure of the probe to $\mathrm{O}_{2}$ during handling prior to deployment, resulting in the formation of Fe oxides during the deployment. Note that the October 2001 core \#1 data point at $2 \mathrm{~cm}$, which had undetectable dissolved Fe and Mn concentrations and RSM concentrations that were twice their bottom water concentrations at that depth, has been omitted from the RSM plots since it was clearly influenced by a burrow.

Figure 7: Composite profiles of $\mathrm{U}, \mathrm{Re}$, and Mo and best-fit model profiles. At each time point, the "composite" U, Mo, and Re profiles, calculated as described in the text, are shown with open circles. The composite cores were used with the pore water RSM model to derive best-fit model parameters, which resulted in the best-fit model profiles denoted by solid black lines. Overlying water concentrations are denoted by an asterisk.

Figure 8: $\mathrm{Br}^{-}$versus time in flux chambers in experiments carried out from June 2001 June 2004. The three different line styles indicate three different model runs: the dotted line is predicted by the irrigation model if only vertically-oriented, ionic diffusion transports the $\mathrm{Br}$. The dashed line is the best fit of the model to the data if 
the irrigation parameter takes the form, $\alpha=\alpha_{0} e^{-\alpha_{1} x}$. The solid line is the best fit if $\alpha$ is assumed to be constant from $x=0$ to $x=8 \mathrm{~cm}$, and $\alpha=0$ below $8 \mathrm{~cm}$. In June $2001 \operatorname{ch} 3$ and May 2002ch3, neither the constant- $\alpha, L=8$ model nor the exponentially-decreasing $\alpha$ model could reproduce the large observed $\mathrm{Br}^{-}$decreases over time. It is possible that below the penetration depth of the chambers $(\sim 12 \mathrm{~cm})$, lateral transport removed $\mathrm{Br}^{-}$, both by diffusion and by transport through burrows; therefore, the one-dimensional model cannot explain the results, and the $\alpha$ calculated from the $\mathrm{Br}^{-}$data cannot be applied to other solutes since they will not be affected by the lateral transport in the same way as the tracer. In the two experiments of October 2002, the $\mathrm{Br}^{-}$data show discontinuous decreases in $\mathrm{Br}^{-}$. These results can be attributed to irrigation "events" occurring at specific times during the experiments. For example, in chamber 4 (ch4) the decrease after 3 days occurred after the $\mathrm{O}_{2}$ concentration in the chamber had decreased to near zero.

Figure 9: A. Fluxes across the sediment-water interface. Fluxes of $\mathrm{TCO}_{2}$ and $\mathrm{NH}_{4}{ }^{+}$are directed out of the sediments, while those of $U$ and Mo are directed into the sediments. For each solute, at each time period, 4 fluxes are shown: (1) the total flux as determined from benthic chamber measurement $\left(\mathrm{F}_{\mathrm{C}}\right),(2)$ the diffusive flux across the sediment-water interface, calculated from pore water profiles $\left(\mathrm{F}_{\mathrm{D}}\right),(3)$ the calculated irrigation flux, from the pore water profile and equations 4 and $5\left(\mathrm{~F}_{\mathrm{I}}\right)$, and (4) the sum of (2) and (3) $\left(\mathrm{F}_{\mathrm{D}}+\mathrm{F}_{\mathrm{I}}\right)$. B. The reaction factor, $f_{\mathrm{i}}$, for each element. The open circles indicate the value calculated at each time and the filled circle shows the mean and standard deviation for each solute. Note that the January, 2002 time point was excluded from the average for $\mathrm{TCO}_{2}$ and $\mathrm{NH}_{4}^{+}$(see text). 
Figure 10: Solid phase Fe, Mn, U, and Mo profiles at the Hingham Bay site, measured in three cores taken in 2002. Vertical bars in the U and Mo plots show (A) the average metal concentration in the region of the minimum in the profile and (B) the average metal concentration in the region judged to be below the zone of authigenic metal formation. In our calculations, we assume that $(\mathrm{A})$ is the detrital metal concentration and that the authigenic metal concentration is the difference between (B) and (A).

Figure 11: Authigenic metal concentrations as a function of sedimentation rate, calculated from equation 8 using either the diffusive flux of the metal at $x=x_{p}$ (solid line) or the total flux determined from benthic chamber measurements (dashed line). The calculated values are compared to the range in authigenic metal concentrations inferred from solid phase data (Figure 10) and the average sedimentation rate that was estimated for the period, $1978-2000$. 


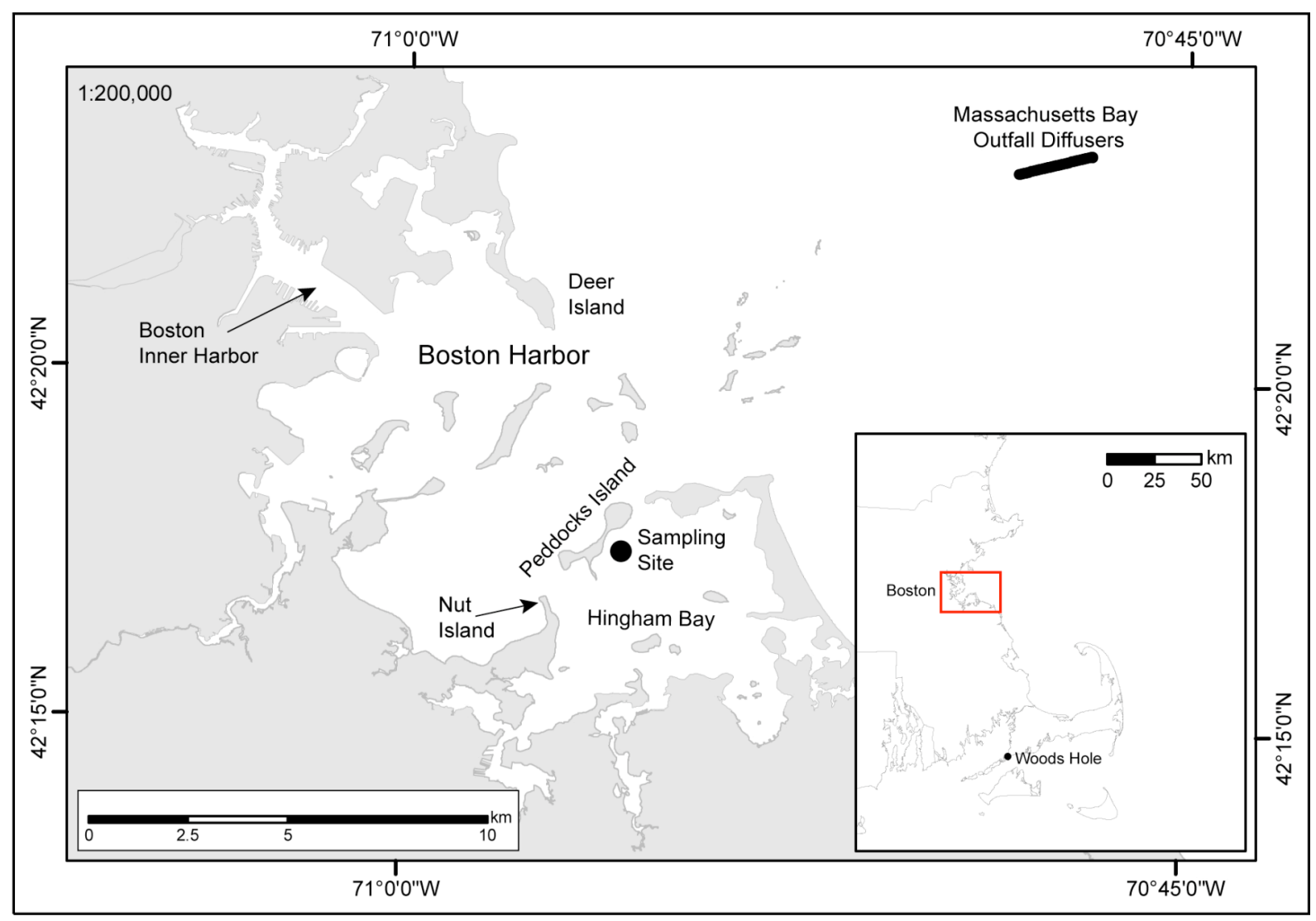

Figure 1 

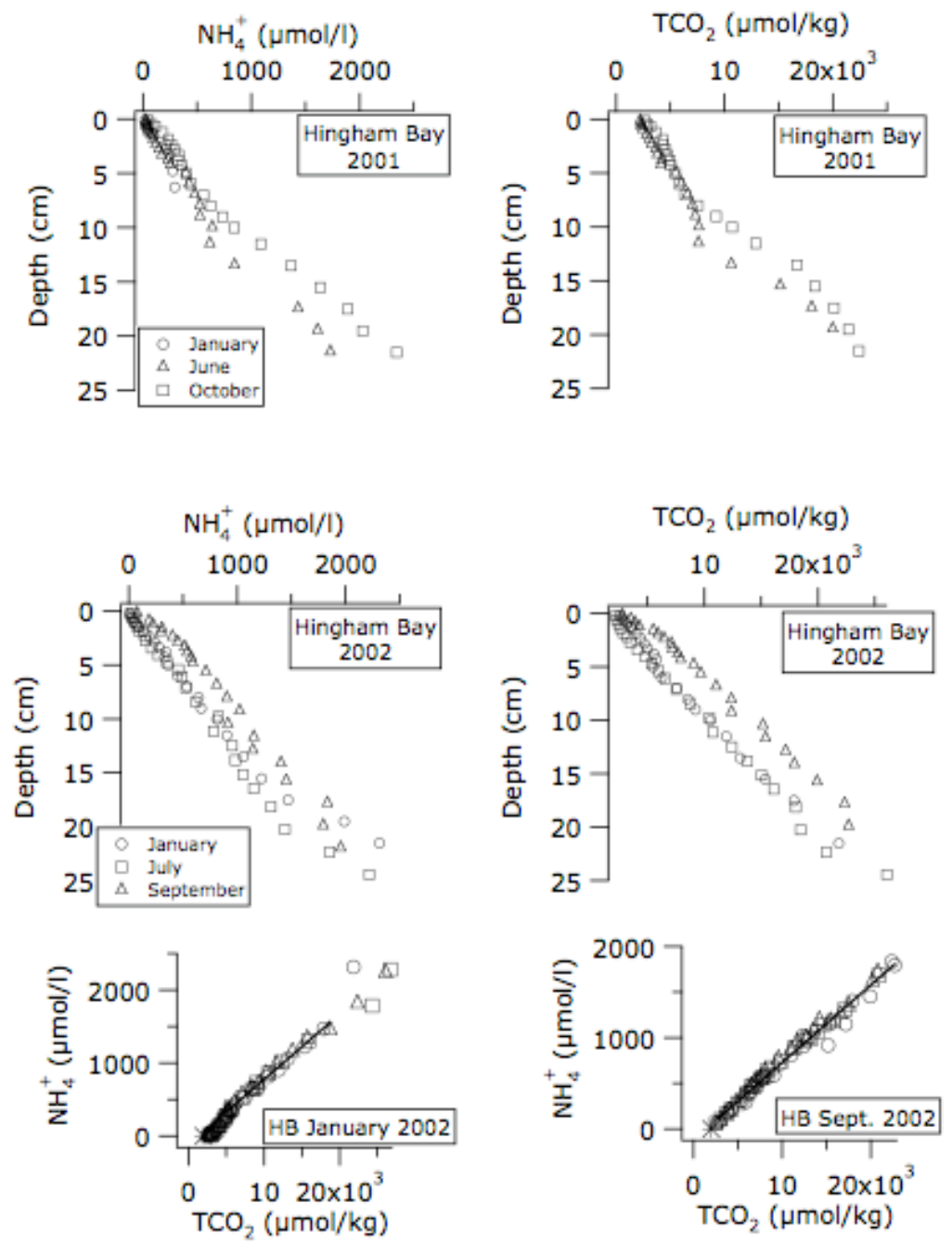

Figure 2. 

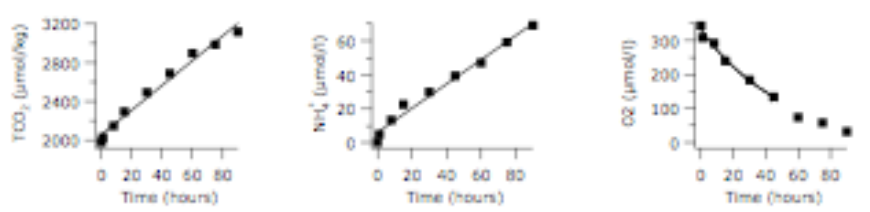

A
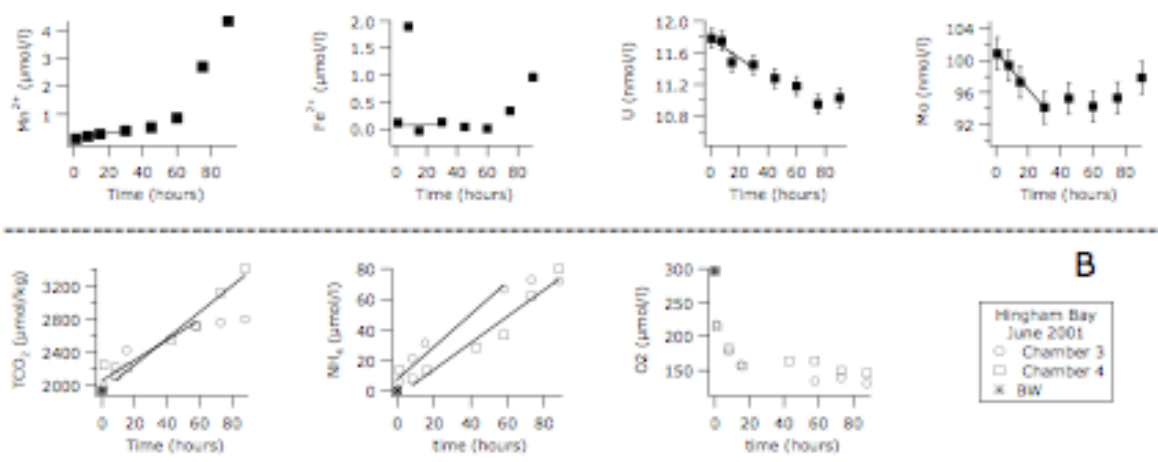

\begin{tabular}{|l} 
Hergian Byy \\
Laniary 2003
\end{tabular}
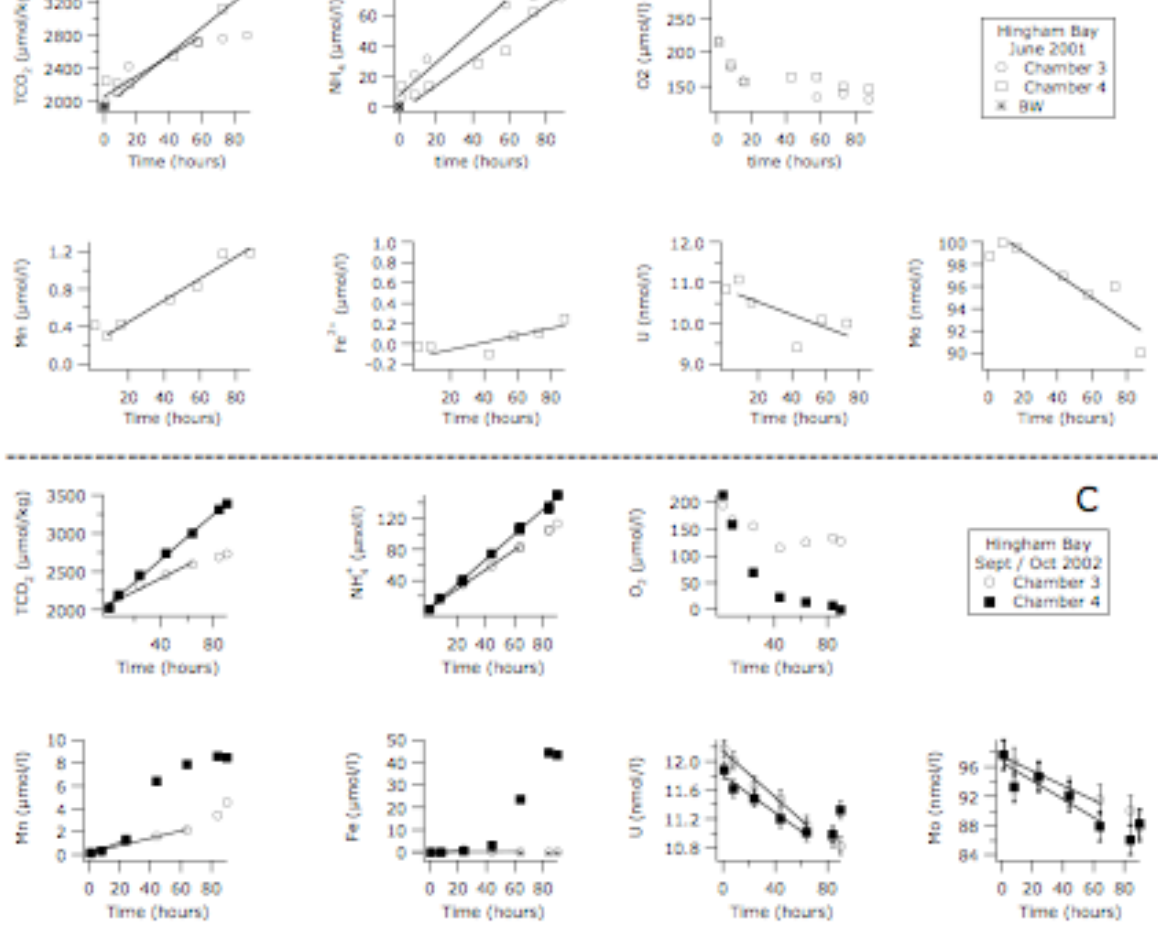

Figure 3. 

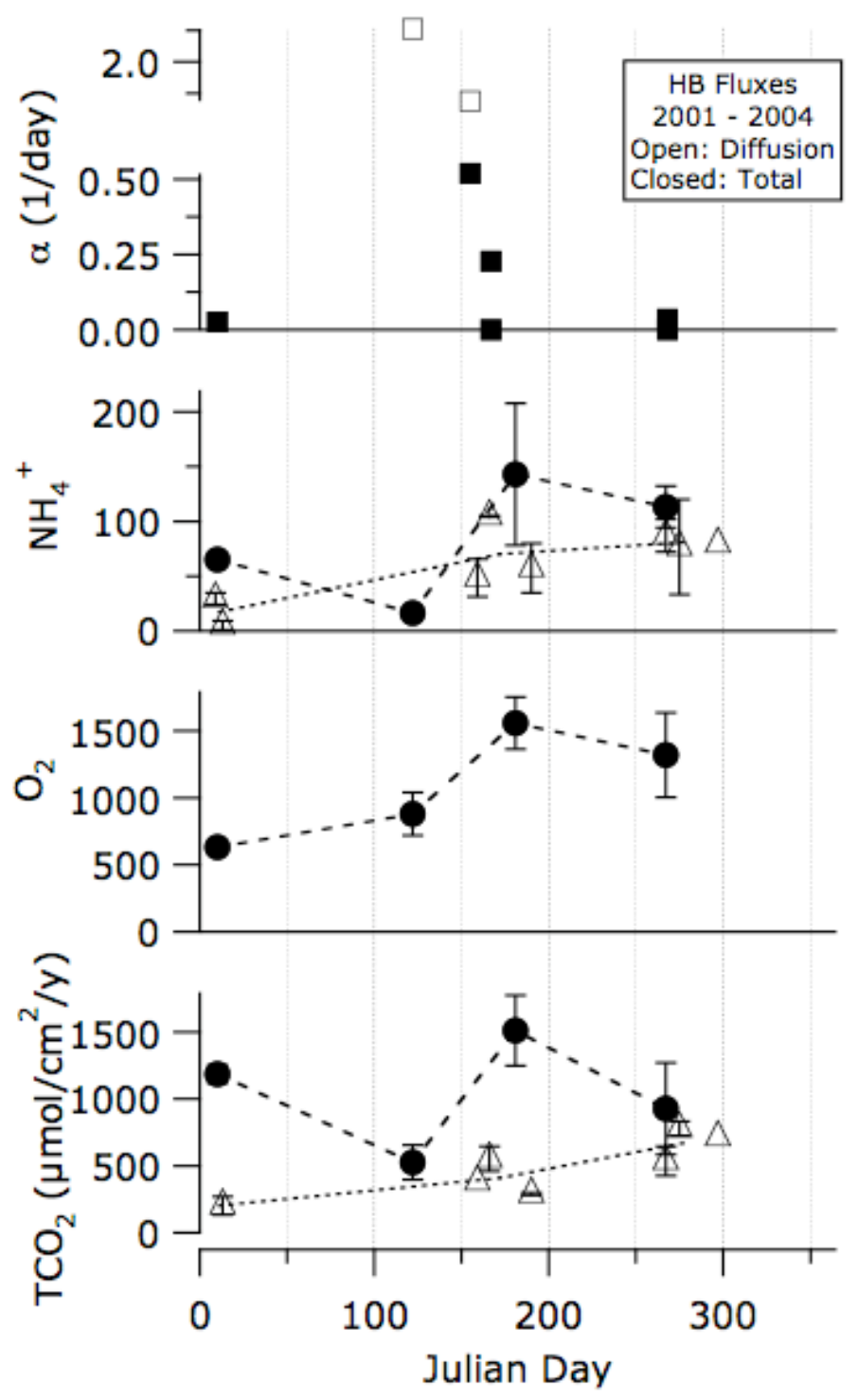

Figure 4. 

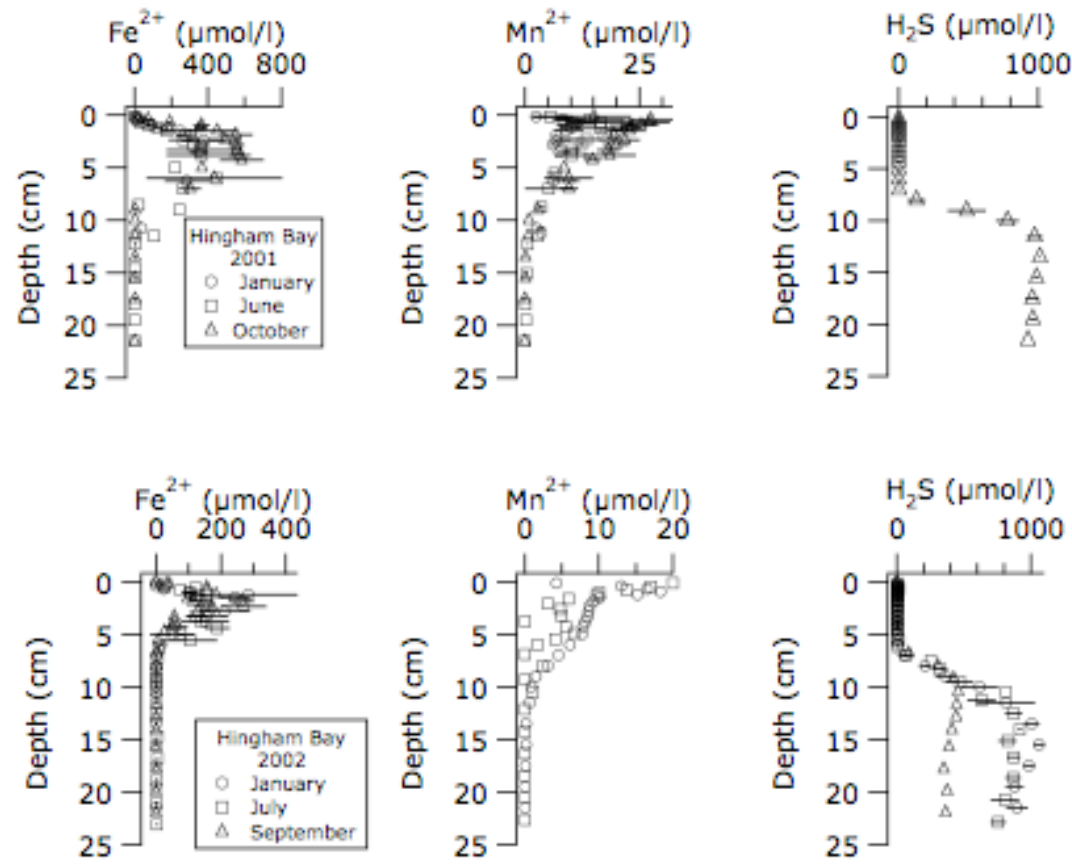

Figure 5. 

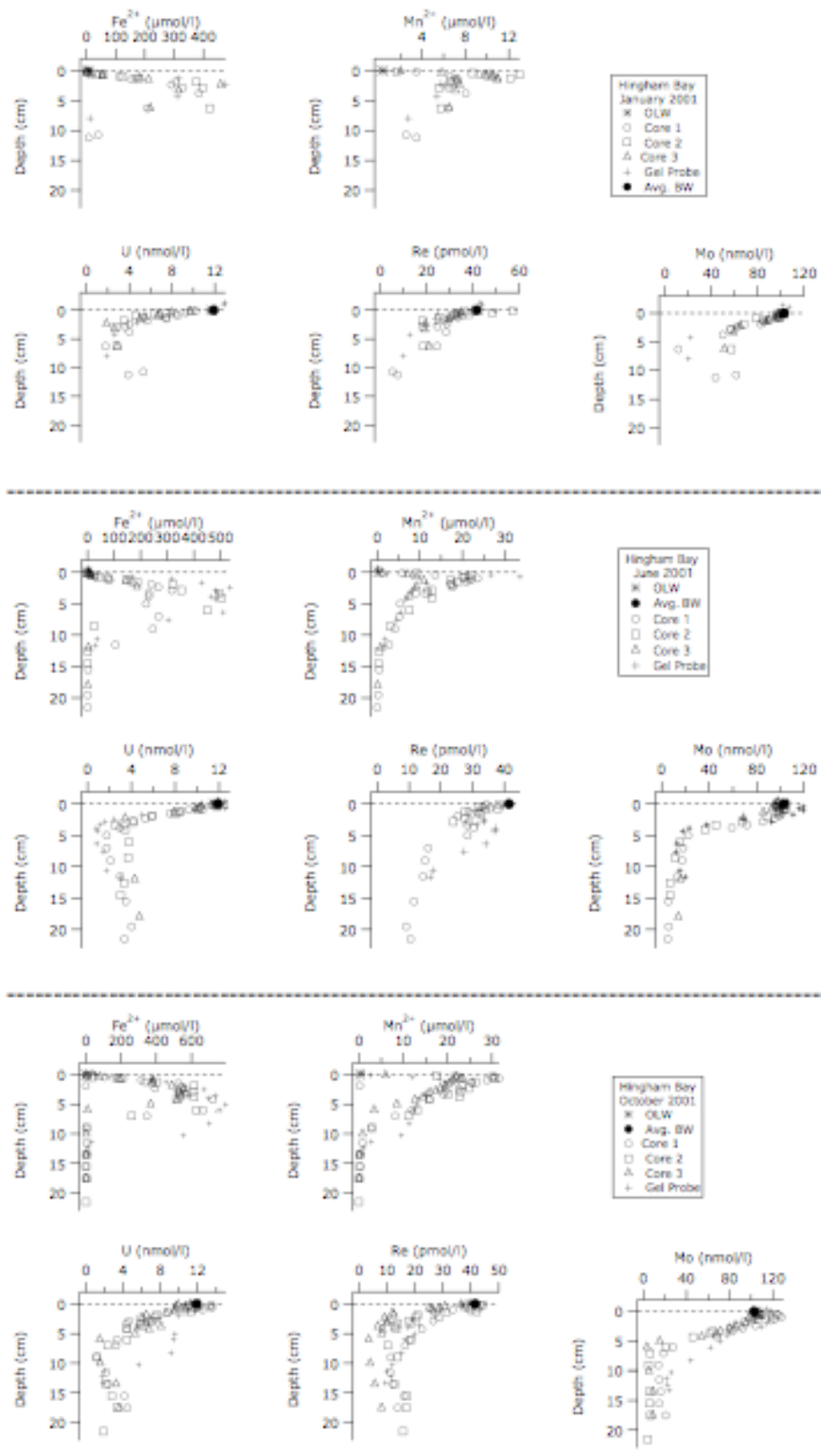

Figure 6. 

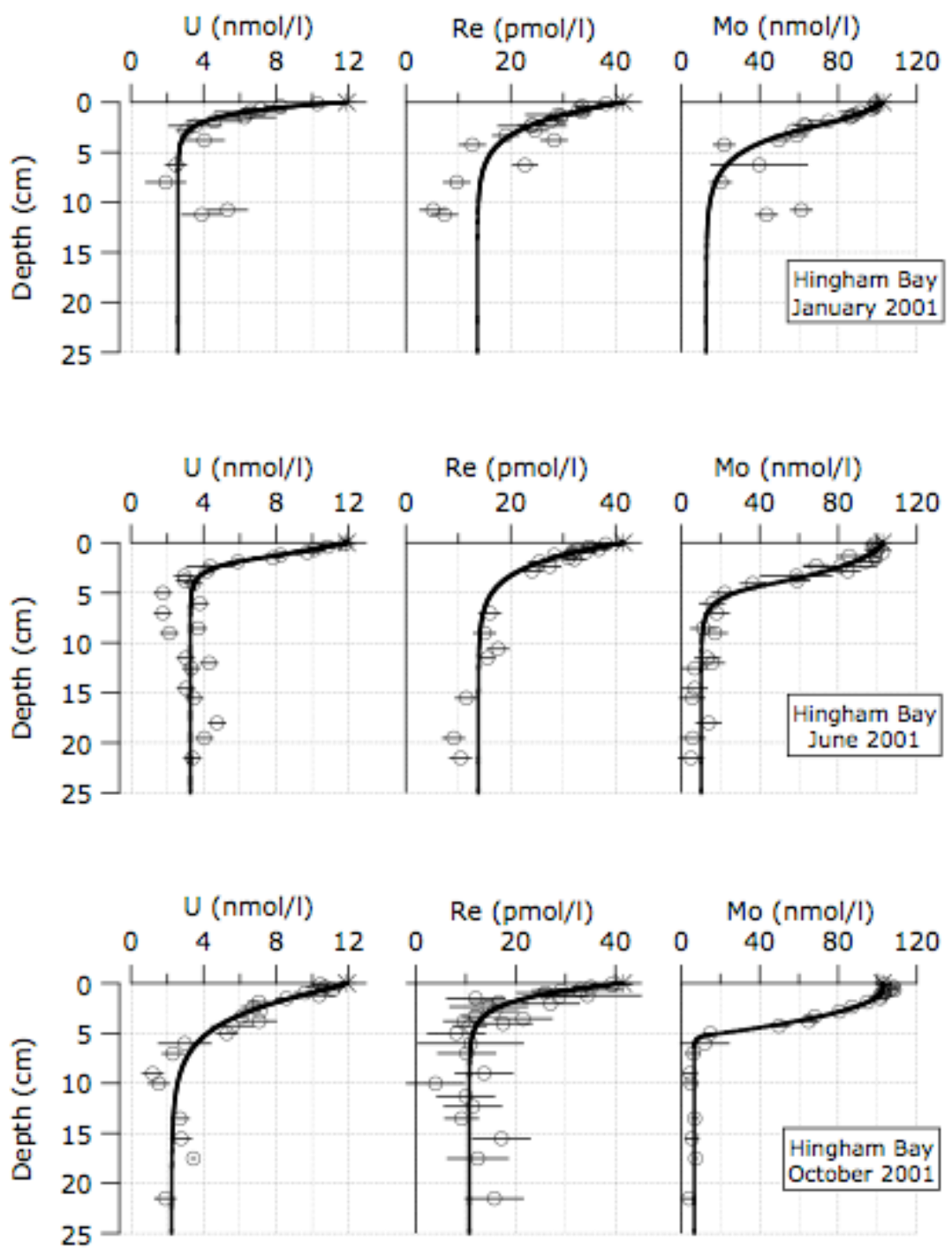

Figure 7. 

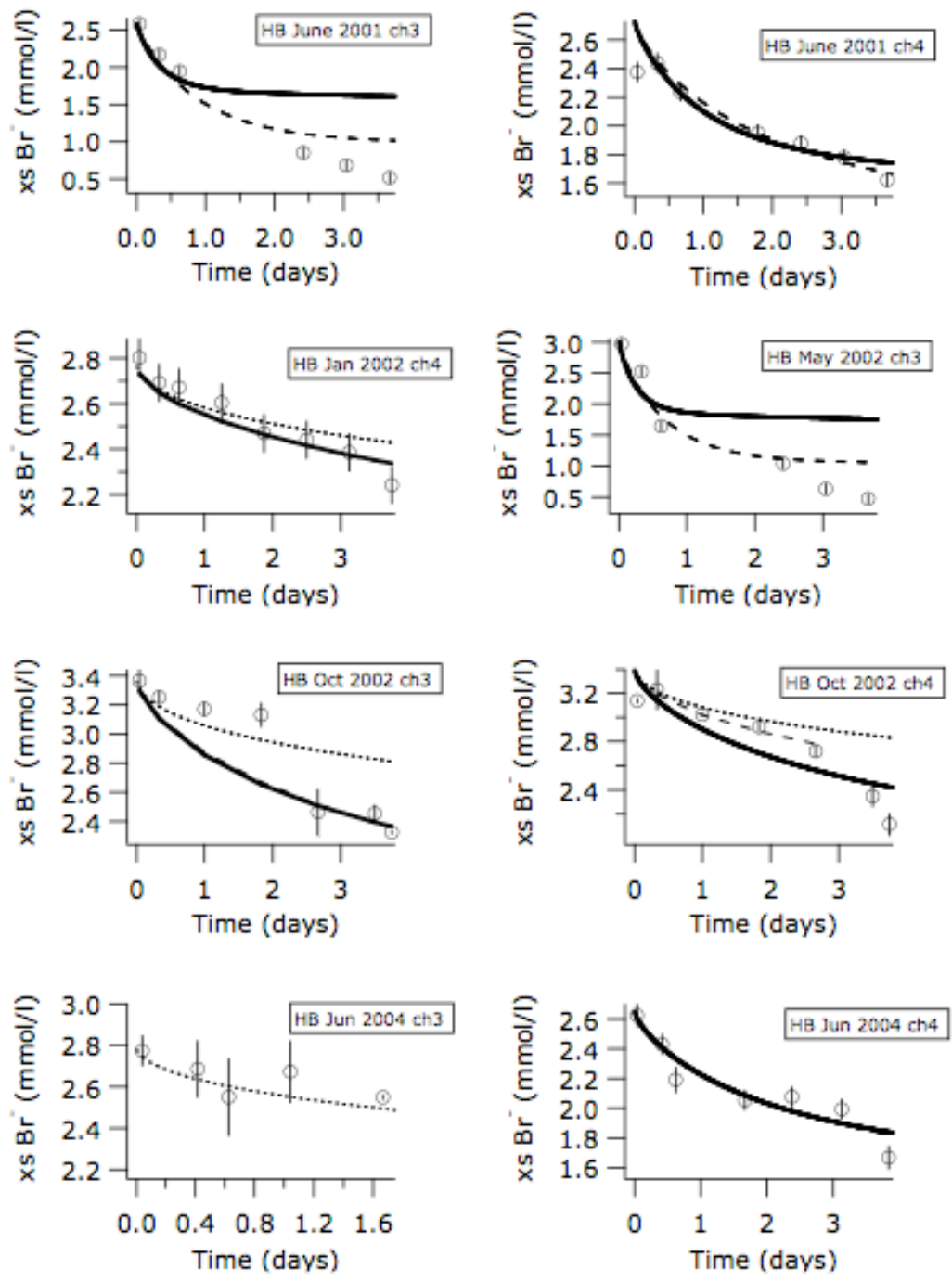

$$
\begin{aligned}
& \text { Data } \\
& \text { - - Fit: } \alpha_{0}, \alpha_{1} \text { vary } \\
& \text { - Fit: Const. } \alpha, \mathrm{L}=8 \\
& \text { … Diffusion only }
\end{aligned}
$$

Figure 8. 


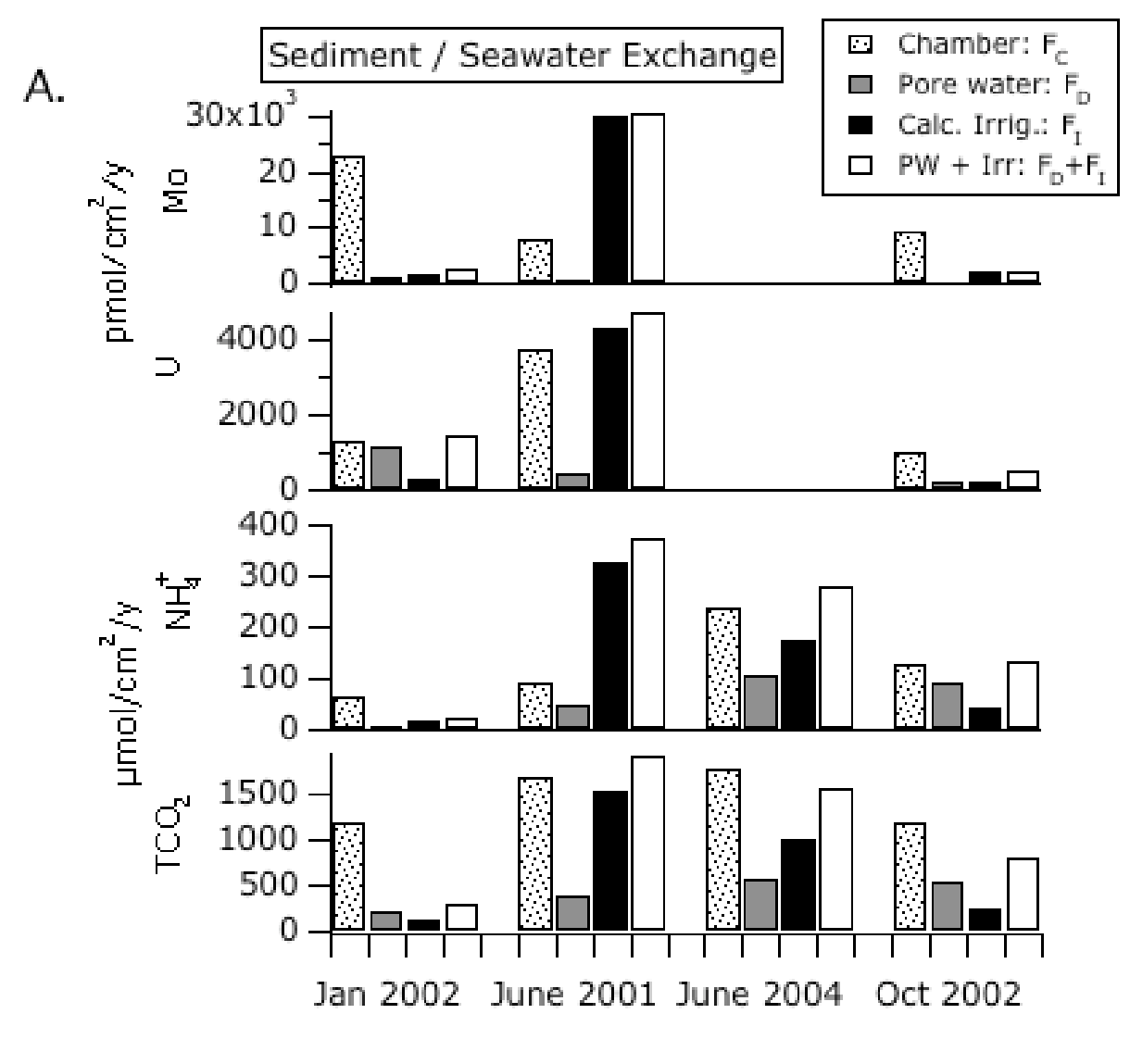

B.

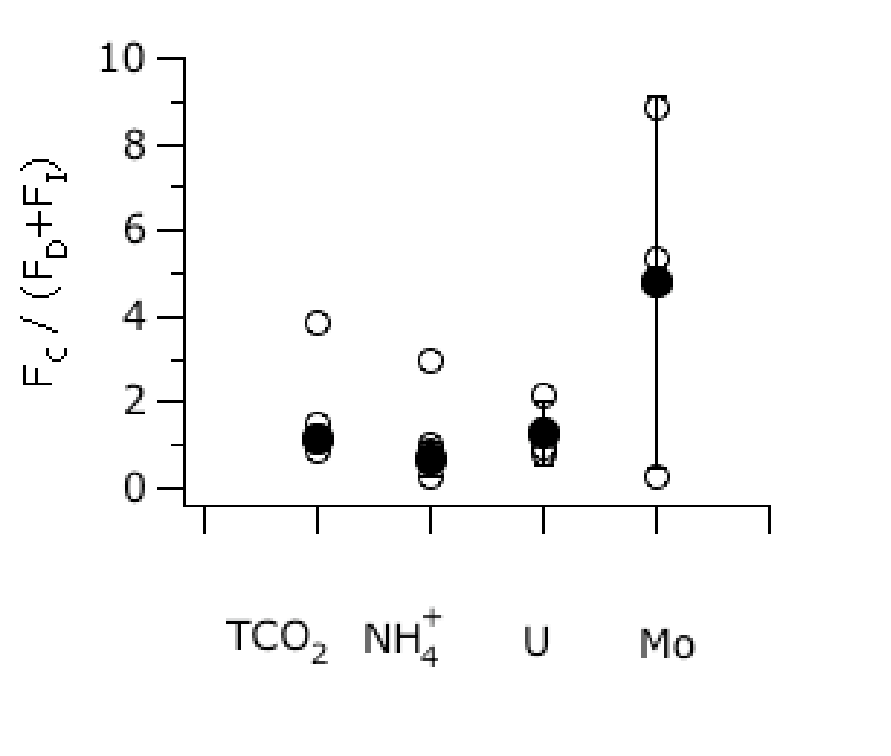

Figure 9. 

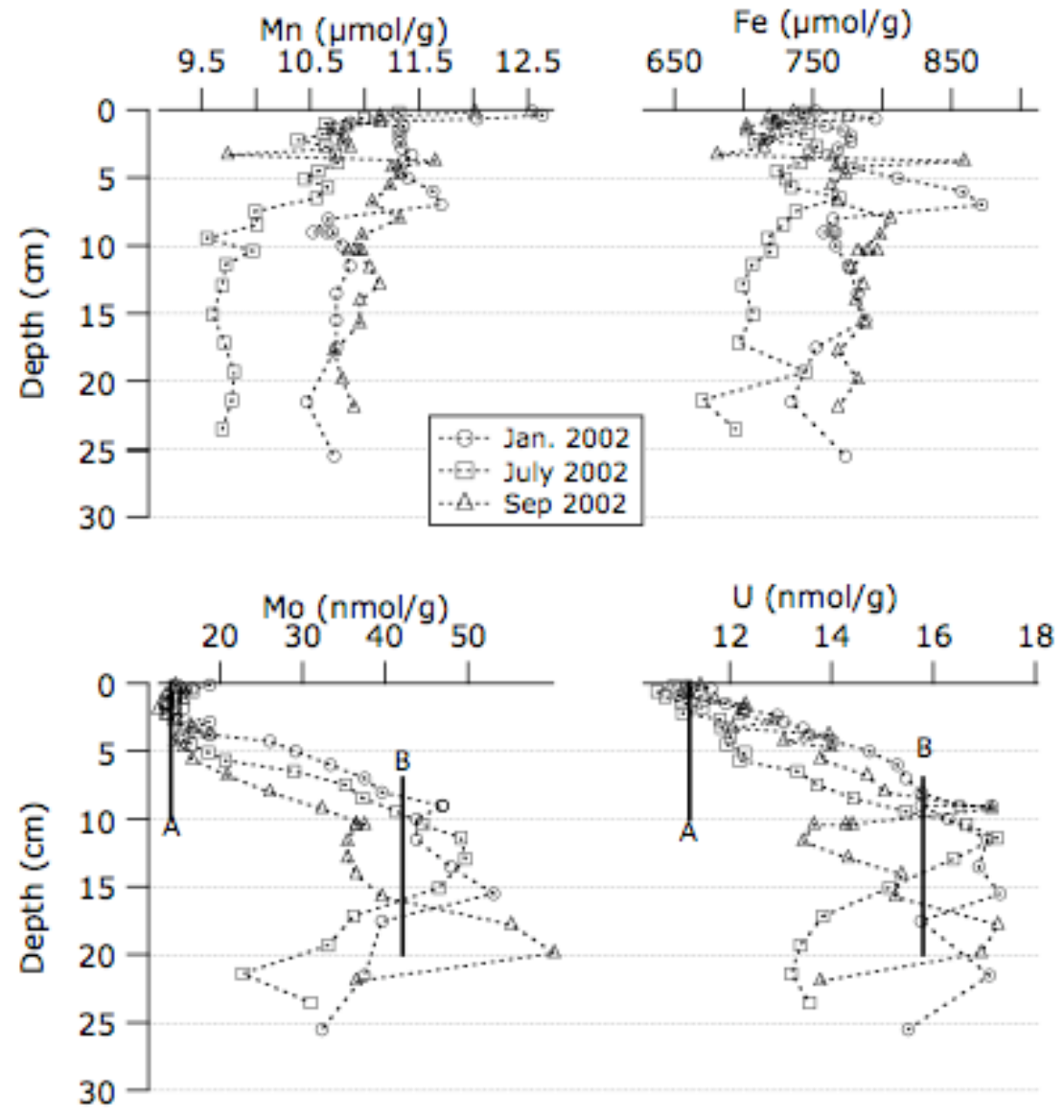

Figure 10. 

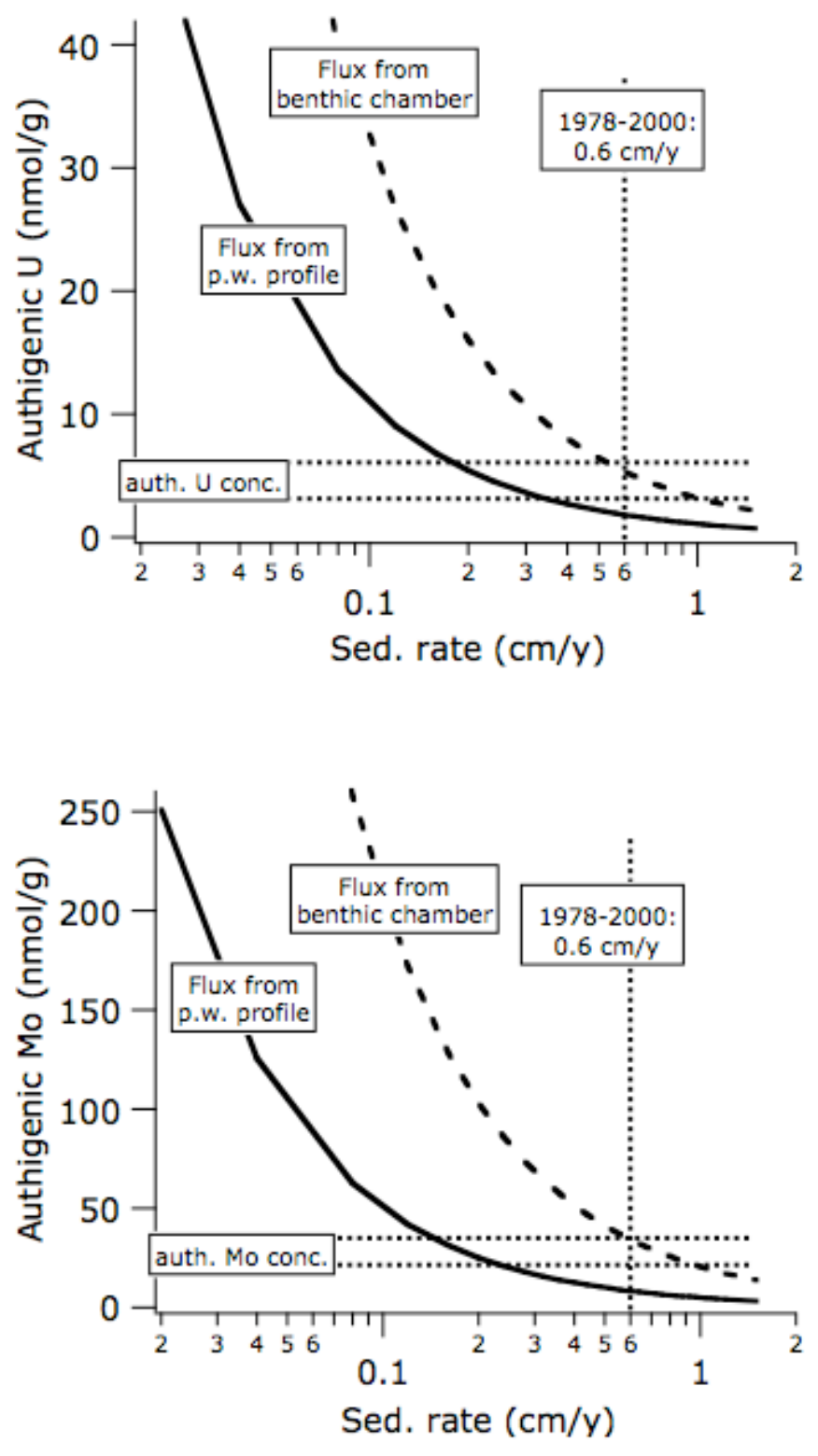

Figure 11. 